Document downloaded from:

http://hdl.handle.net/10251/168620

This paper must be cited as:

Carceller-Carceller, JM.; Mifsud, M.; Climent Olmedo, MJ.; Iborra Chornet, S.; Corma Canós, A. (2020). Production of chiral alcohols from racemic mixtures by integrated heterogeneous chemoenzymatic catalysis in fixed bed continuous operation. Green Chemistry. 22(9):2767-2777. https://doi.org/10.1039/c9gc04127c

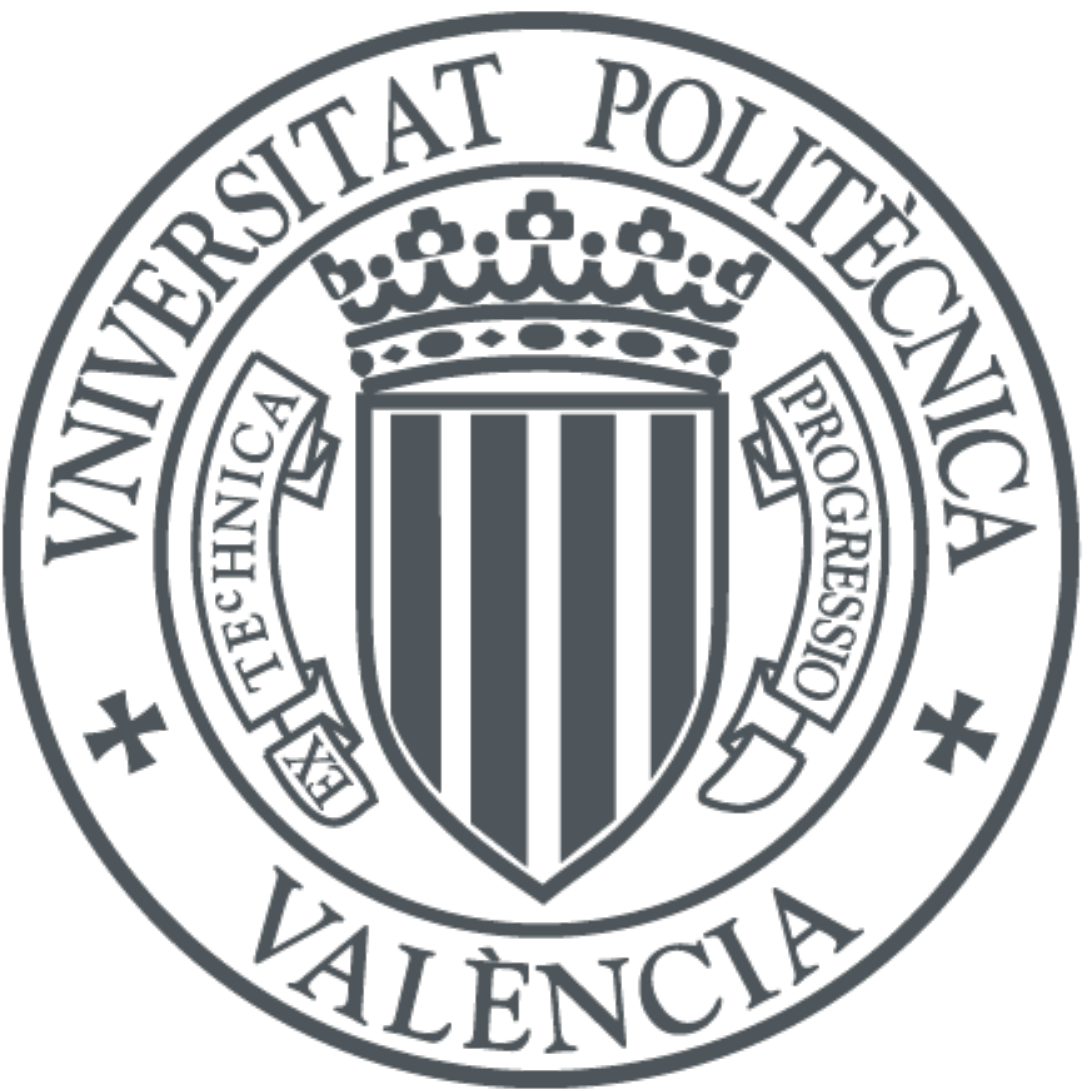

The final publication is available at

https://doi.org/10.1039/c9gc04127c

Copyright The Royal Society of Chemistry

Additional Information 


\title{
Production of chiral alcohols from racemic mixtures by integrated heterogeneous chemoenzymatic catalysis in fixed bed continuous operation
}

Received 00th January 20xx, Accepted 00th January 20xx

DOI: $10.1039 / \times 0 \times x 00000 x$

\author{
Jose Miguel Carceller, ${ }^{\mathrm{a}}$ Maria Mifsud, ${ }^{\mathrm{a}}$ Maria J. Climent, ${ }^{\mathrm{a}}$ Sara Iborra, ${ }^{{ }^{\mathrm{a}}}$ and Avelino Corma* ${ }^{\mathrm{a}}$
}

\begin{abstract}
Valuable chiral alcohols have been obtained from racemic mixtures with an integrated heterogeneous chemoenzymatic catalyst in a two consecutive fixed catalytic bed continuous reactor system. In the first bed the racemic mixture of alcohols is oxidized to the prochiral ketone with a Zr-Beta zeolite and using acetone as hydrogen acceptor. In the second catalytic bed the prochiral ketone is stereoselectively reduced with an alcohol dehydrogenase (ADH) immobilized on a two dimensional (2D) zeolite. In this process, the alcohol (isopropanol) formed by reduction of acetone in the first step, reduces the cofactor in the second step, and the full reaction cycle is in this way internally closed with $100 \%$ atom economy. Conversion about $95 \%$ with 100 \% selectivity to either the (R) or the (S) alcohol have been obtained for a variety of racemic mixtures of alcohols.
\end{abstract}

\section{Introduction}

One of the main demands of modern chemistry is the easy syntheses of optically pure compounds, ${ }^{1}$ and resolution of racemic mixtures is the most common method to prepare enantiomerically pure compounds at an industrial scale. ${ }^{2,3}$ Chiral secondary alcohols are valuable intermediates in the fine chemical industry. For example, the pure chiral ( $R$ or $S$ )-2octanol and (S)-2-pentanol are important precursors for the preparation of several drugs for the treatment of Alzheimer. ${ }^{4-8}$ The easy accessibility and commercial availability of an abundant variety of racemic alcohols have promoted the development of biocatalytic routes to produce enantiopure alcohols from racemic mixtures. ${ }^{9}$ Most protocols being used to produce chiral alcohols are based on kinetic resolutions (KR) of racemic secondary alcohols with enzymes such as lipases and esterases. ${ }^{10,11}$

Enzymatic kinetic resolution is often very efficient in terms of selectivity but suffers of important drawbacks, such as the maximum theoretical yield is limited to $50 \%$ due to the consumption of only one enantiomer, while it requires a laborious separation of the product from the remaining substrate. An attractive method to overcome those drawbacks is the dynamic kinetic resolution (DKR) in which racemisation of unwanted enantiomer is coupled in one-pot with $K R$, and

\footnotetext{
a. Instituto de Tecnologia Química (UPV-CSIC), Universitat Politècnica de València, Avda dels Tarongers $s / n, 46022$, Valencia (Spain)

† Footnotes relating to the title and/or authors should appear here.

Electronic Supplementary Information (ESI) available: [details of any supplementary information available should be included here]. See DOI: $10.1039 / \mathrm{x} 0 \times x \times 0000 \mathrm{x}$
}

then a theoretical maximum yield of up to $100 \%$ can be achieved. $^{12-14}$

Another strategy for deracemization of secondary alcohols that has attracted much attention is based on simple oxidation-reduction sequences that are usually accomplished by multienzymatic combinations. ${ }^{15-18}$ However, it is also possible to achieve deracemization by combining a chemocatalyzed non-selective oxidation step of the racemic alcohols with stereoselective (enzymatic) reduction of the prochiral ketone. This protocol has been comparatively less explored, and it is usually accomplished using homogeneous chemoenzymatic catalytic systems based in the combination of and oxidant such as TEMPO (2,2,6,6-tetramethylpiperidin-1oxyl) or AZADO (2-azaadamantane $\mathrm{N}$-oxyl) with redox biocatalysts such alcohol deshydrogenases (ADH). ${ }^{19-22}$

Here, we present an efficient process to obtain valuable chiral alcohols from racemic mixtures with an integrated heterogeneous chemo/enzymatic two steps relay catalyst. ${ }^{23}$ With this strategy we have coupled two steps in a continuous process: the first step is the oxidation of a racemic mixture of secondary alcohols into a prochiral ketone through the Oppenauer Oxidation using a Lewis acid zeolite (Zr-Beta) followed by the stereoselective reduction of the prochiral obtained ketone to alcohol with the enzyme alcohol dehydrogenase (ADH) immobilized on a two-dimensional (2D) zeolite (ITQ-2) (Scheme 1). Finally, the alcohol formed as byproduct in the Oppenauer reaction reduces the cofactor closing the system with $100 \%$ atom economy. This strategy allows obtaining optically pure alcohols without having to isolate and purify intermediates, reducing the number of separation steps with the corresponding benefit from the environmental and economic point of view. 


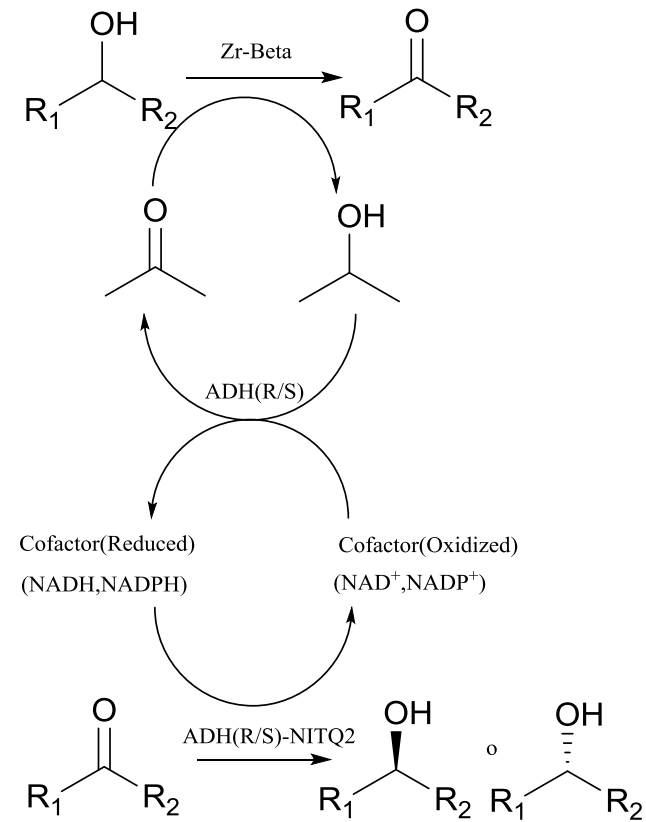

Scheme 1. Coupling Oppenauer oxidation of racemic mixtures of alcohol with stereoselective reduction of the prochiral ketone with immobilized ADH

The Meerwein-Ponndorf-Verley (MPV) reduction of aldehydes and ketones and the reverse Oppenauer oxidation of alcohols (MPVO) are valuable tools in organic synthesis since they are chemoselective reactions in which other reducible or oxidizable groups are not reacted, moreover they can be performed under mild conditions. Basically, in the MPVO reaction, a carbonyl compound is reduced to an alcohol molecule while an alcohol is oxidized to the corresponding carbonyl compound through a hydride transfer process. The conventional catalysts used in MPVO reactions are aluminum alkoxides, however the stoichiometric amount of alkoxide required, its water sensitivity, along with the required neutralization at the end of the reaction and wastes generated are important disadvantages. Therefore, in the last years a variety of heterogeneous catalysts have been developed and successfully applied in this process. Among them, Al- and TiBeta zeolites have been reported as excellent catalysts for MPVO reactions showing that Lewis acid sites are the active sites of the catalyst. ${ }^{24-27}$ Compared with Al- and Ti-Beta zeolites, better performances for the MPVO reactions were found using Sn- and Zr-Beta zeolites which was attributed to the more adequate Lewis acidity of the $\mathrm{Sn}$ and $\mathrm{Zr}$ sites in the zeolite framework. ${ }^{28-31}$ A computational study indicates that the mechanism of Sn-Beta and Zr-Beta catalysts is similar and consists of three steps: adsorption of both ketone and the alcohol on the Lewis acid site, deprotonation of the alcohol, carbon-to-carbon hydride transfer, and proton transfer from the catalyst and product exchange. ${ }^{30}$ The exceptional characteristics of Sn-Beta and Zr-Beta zeolites as highly active and stable catalysts for the MPVO reaction, prompted us to select the Zr-Beta zeolite as catalyst to produce the oxidation of racemic alcohols into prochiral ketones as the first step of the process proposed here. On the other hand, alcohol dehydrogenases $(A D H)$ are enzymes that reversibly catalyse the reduction of aldehydes or ketones to primary or secondary alcohols respectively. They play an increasingly important role for the production of chiral alcohols, hydroxyl-acids or aminoacids. $^{32,33}$ However, comparatively with hydrolytic enzymes, such as lipases, reductases have been considerably less used in the production of optically active compounds, due to an important limitation for industrial applications of ADH is the need of stoichiometric amounts of expensive co-factors (NADH or NADPH). Reductions using ADH are only economically feasible if an efficient regeneration of the reduced cofactor is possible. Efficient methods for the regeneration of the cofactor allowing their use in catalytic amounts are the use $\mathrm{ADH}$ in combination with other substrate/enzyme systems such as formate/formate dehydrogenase or glucose/glucose dehydrogenase. However, one of the cheapest method for cofactor regeneration is by using isopropanol as a substrate of $\mathrm{ADH} .{ }^{34-36}$ The use of isopropanol is very convenient since it can also be used as a co-solvent for homogeneous solutions of organic substrates.

In the case of enzymes, their immobilization on solids supports may be adapted for increasing the stability and reaction kinetics of the enzyme $e^{37,38}$ and, more importantly from the industrial point of view, the immobilization allows the easy separation from the reaction mixture, enzyme recyclability and the possibility to be used in continuous operation process. In this context the co-immobilization of enzymes and cofactor on solid materials is an interesting approach for large scale biotransformations. ${ }^{39-42}$ For instance, Lopez-Gallego et al. ${ }^{40}$ have integrated enzymes and phosphorylated cofactors on agarose microbeads activated with polyethyleneimine. They reported the first example of asymmetric reduction of ketones using co-immobilized $\mathrm{ADH}$ and $\mathrm{NAD}^{+}$in continuous flow reactor observing an insignificant $\mathrm{NAD}^{+}$lixiviation, which is one of the main limitations of the immobilized nicotinamide cofactor.

$\mathrm{ADH}$ have been immobilized by entrapment, covalent, or electrostatic interactions over different carriers. For instance, $\mathrm{ADH}$ has been immobilized on glyoxyl-agarose, ${ }^{43}$ silica nanotubes, ${ }^{44}$ magnetic nanoparticles, ${ }^{45,46}$ polyaniline coated silver nanoparticles, ${ }^{47}$ magnetic graphene oxide nanocomposites ${ }^{48}$ and more recently over mesoporous silica ${ }^{49}$ and titania nanoparticles. ${ }^{50}$ However, when working with mesoporous materials, and depending on the size of the enzyme, hindered diffusion of the coenzyme and/or substrate through the porous system of the support can occurs limiting mass transport, affecting negatively the catalytic activity. Therefore, in this work we have selected as support for immobilization $\mathrm{ADH}$ a pure silica 2D zeolite (ITQ-2 zeolite). ITQ-2 zeolite can be prepared by delamination of a layered MWW zeolite precursor or by a dual templating one step 
synthesis. ${ }^{51-54}$ The resulting ITQ-2 zeolite is a crystalline material highly stable in aqueous media formed by thin zeolite sheets (2.5 nm thick) containing regularly distributed silanol groups and high external surface area $\left(\sim 600 \mathrm{~m}^{2} \mathrm{~g}^{-1}\right)$. On these structured inorganic sheets, the enzyme can be easily grafted and diffusional problems of the coenzyme and substrate are not expected. The large external surface area of ITQ-2 zeolite along with their high stability in aqueous media converts this material in an excellent and stable enzyme carrier for industrial biotransformations. ${ }^{55,56}$

Taking into account the above considerations, we have envisaged here a cascade process to produce chiral secondary alcohols starting from racemic mixtures in a continuous process by combining two fixed bed continuous reactor. In the first bed the alcohol racemic mixture is oxidized to a prochiral ketone through a hydrogen transfer reaction, the Oppenauer oxidation, using acetone as hydrogen acceptor and $\mathrm{Zr}$-Beta zeolite as Lewis acids catalyst. In this reaction, isopropanol is produced as by-product. Then, the mixture of the prochiral ketone and isopropanol goes through the second catalytic bed containing the immobilized ADH on ITQ-2 in where after adjusting the amount of isopropanol and cofactor (NADH or NADPH) the stereoselective reduction of the ketone is produced, while the acetone used in the first step is regenerated.

\section{Results and discussion}

\section{Characterization of the support and immobilization of ADH}

For enzyme immobilization through electrostatic interactions, the surface of the pure silica ITQ-2 zeolite was functionalized with amino groups by treating the zeolite with (3aminopropyl)triethoxysilane (material labelled as NITQ-2). Elemental analysis of the sample confirmed the presence of $2,5 \mathrm{wt} \%$ of nitrogen on the material which corresponds to a functionalization density of amino groups of $1.8 \mathrm{mmol} / \mathrm{g}$ (see Table S1). The FTIR analysis of the ITQ-2 and NITQ-2 are presented in Figure S1. Stretching vibration bands corresponding to $\mathrm{Si}-\mathrm{OH}$ groups are observed in the ITQ-2 pure silica sample at $3740 \mathrm{~cm}^{-1}$ (Figure S1(a)). After chemical modification with (3-aminopropyl)triethoxysilane, the stretching vibration bands associated to amino groups at 3426 $\mathrm{cm}^{-1}$ and $1658 \mathrm{~cm}^{-1}$ along with, the stretching vibration of $\mathrm{CH} 2$ groups $\left(2928 \mathrm{~cm}^{-1}, 2866 \mathrm{~cm}^{-1}\right)$ associated to the alkyl chain of the propyl group are observed (Figure S1(b)), confirming the presence of the aminopropyl groups. Moreover the intensity of the $3740 \mathrm{~cm}^{-1}$ corresponding to $\mathrm{Si}-\mathrm{OH}$ groups has very strongly decreased due to the anchoring the (3aminopropyl)triethoxysilane. The Brunauer-Emmett-Teller surface area of the unmodified ITQ-2 was calculated to be 756 $\mathrm{m}^{2} / \mathrm{g}$, and after modification with (3aminopropyl)triethoxysilane the BET surface area was decreased up to $387 \mathrm{~m}^{2} / g$, however it still represents a high surface area support where the enzyme can be anchored (see Table S2).
The isoelectronic point (ip) of the ADH was determined to be at $\mathrm{pH}=4.5$ (see experimental), while the ip of the aminopropilated siliceous support should be in basic range, ${ }^{49}$ therefore $\mathrm{a} \mathrm{pH}=5.5$ was selected for immobilization of the enzyme through electrostatic interactions. Thus, the immobilization of the enzyme $(A D H(S)$ and $A D H(R)$ was performed by incubating the enzyme $(10 \mathrm{mg})$ with the NITQ-2 $(200 \mathrm{mg}$ ) in a phosphate buffer solution at pH 5.5 during $24 \mathrm{~h}$. The amount of protein immobilized was determined by analyzing the amount of free enzyme in the supernatant by bicinchoninic acid protein test. After $24 \mathrm{~h}$ of incubation it was determined that the amount of immobilized ADH was $86 \%$ while the activity recovery ${ }^{57}$ was $80 \%$, which agrees with the calculated amount of enzyme immobilized.

\section{Properties of Immobilized ADH}

To determine the different properties of immobilized ADH on NITQ-2 we selected as reaction model the reduction of 2octanone into (S)-2-octanol. Reactions were performed at 25 ${ }^{\circ} \mathrm{C}$ using a molar ratio substrate/NAD ${ }^{+}$of $10 / 1$ which is the recommended ratio by the supplier. ${ }^{46,58,59}$

First, we studied the effect of enzyme loading on the catalytic activity by varying the amount of enzyme on the support as showed in Table 1. As can be observed, during the preparation of the supported enzyme, when the ratio enzyme/support (wt/wt) is duplicated (entries 1 and 2), the amount of immobilized enzyme decreases from $86 \%$ (entry 1) to $75 \%$ (entry 2). When the ratio of enzyme/support (entry 3) was reduced the amount of immobilized enzyme resulted $100 \%$. When the catalytic activity for the reduction of 2-octanone was tested for these different samples (Figure S2), it is possible to see that samples of entry 1 and 2 perform similar, achieving total conversion of the ketone after $30 \mathrm{~min}$ reaction time (see Figure S2). These results indicate that there is a range of enzyme loadings (between 0.05 and $0.1 \mathrm{~g}$ of enzyme per gram of support) for which the enzymatic derivative maintains very good performance. When the ratio enzyme/support was further decreased (entry 3), as expected, lower initial reaction rate was found, but practically total conversion could still be achieved after $90 \mathrm{~min}$. Notice that the initial reaction rate per mg of enzyme supported remains practically the same independently of the enzyme loading, indicating good accessibility of the substrate to active sites in all cases (Table 1). The sample of entry 1, i.e. those prepared from $10 \mathrm{mg}$ of $\mathrm{ADH}$ on $200 \mathrm{mg}$ of NITQ-2 was selected for performing all the subsequent studies.

Table 1. Effect of enzyme loading on the catalytic activity for the reduction of 2-octanone 


\begin{tabular}{cccccc}
\hline Entry & $\begin{array}{c}\text { Enzyme } \\
(\mathrm{mg})\end{array}$ & $\begin{array}{c}\text { NITQ- } \\
2(\mathrm{mg})\end{array}$ & $\begin{array}{c}\text { Immobilized } \\
\text { Enzyme } \\
(\mathrm{mg})\end{array}$ & $\begin{array}{c}\text { Initial reaction } \\
\text { rate }\end{array}$ & $\begin{array}{c}\text { Initial reaction } \\
\text { rate } / \mathrm{mg} \text { enzyme }\end{array}$ \\
& & & & & \\
\hline 1 & 10 & 200 & 8.6 & 33.5 & 3.89 \\
2 & 10 & 100 & 7.5 & 29.1 & 3.88 \\
3 & 2.5 & 100 & 2.5 & 11.4 & 4.56
\end{tabular}

Immobilization conditions: $10 \mathrm{mg}$ or $2.5 \mathrm{mg}$ of $\mathrm{ADH}(\mathrm{S})$ in $5 \mathrm{~mL}$ of phosphate buffer, $\mathrm{pH}=$ 5.5 ; $200 \mathrm{mg}$ or $100 \mathrm{mg}$ of NITQ-2, under agitation for $24 \mathrm{~h}$. Reaction conditions: 2octanone, $0.3 \mathrm{mmol}(30 \mathrm{mM}), \mathrm{NAD}^{+}, 0.03 \mathrm{mmol}$, in $10 \mathrm{~mL}$ of solvent (Isopropanol/phosphate buffer solution $\mathrm{pH} 7(50 / 50 \mathrm{v} / \mathrm{v})$, at $25^{\circ} \mathrm{C}$.

\section{Catalytic activity as a function of $\mathrm{pH}$ and thermal stability}

To study the effect of $\mathrm{pH}$ on the conversion of 2-octanone into (S)-2-octanol the activity of ADH(S)@NITQ-2 was studied at pH 5.5, 7 and 10 at $25{ }^{\circ} \mathrm{C}$ and compared with the free enzyme (see Figure S3). As can be observed free and immobilized ADH showed maximum activity at $\mathrm{pH}=7$, while acidic $\mathrm{pH}(5.5)$ or basic $\mathrm{pH}$ (10) was detrimental for the enzyme activity. However, the immobilized enzyme was more resistant to the $\mathrm{pH}$ changes, showing higher activity than the native enzyme in a wider range of $\mathrm{pH}$.

The thermal stability of ADH(S)@NITQ-2 was determined by summiting the supported enzyme at different temperatures: 25,35 , and $55{ }^{\circ} \mathrm{C}$ during $1 \mathrm{~h}$ at $\mathrm{pH}$ 7. After that, the substrate 2-octanone was added and the residual catalytic activity was determined under the conditions described in the experimental section. In Figure S4 the residual activity of the free and immobilized enzyme after the thermal treatment is presented. As can be seen there, at $25{ }^{\circ} \mathrm{C}$, the free and immobilized enzyme perform almost the same, giving 80-90 $\%$ conversion after $1 \mathrm{~h}$ reaction time. After treatment at increasing temperatures both the immobilized and native enzyme undergo a strong loss of activity. In fact, $48.3 \%$ conversion with free $\mathrm{ADH}$ was achieved at $35{ }^{\circ} \mathrm{C}$ while the ADH(S)@NITQ-2 gave slightly higher conversion (55.3\%). However, the free enzyme lost completely its activity at $55{ }^{\circ} \mathrm{C}$, while the immobilized enzyme retains a residual activity. Immobilization of ADH can restrict unfolding of the enzyme, and therefore the thermal stability could be somewhat improved with the increase of temperature. ${ }^{48}$ However, these results evidence that for practical uses of the ADH@NITQ-2 the working temperature of the process should not surpass the 25 ${ }^{\circ} \mathrm{C}$.

\section{Scope of the reduction with ADH@NITQ-2}

To study the scope of the reaction we performed the reduction of different ketones using the enzymatic derivative ADH(S)@NITQ-2 under the optimal reaction conditions. Several linear, cyclic and aromatic ketones were selected and as can be observed in Table 2 excellent yields to the (S) enantiopure alcohol with an enatiomeric excess $>99 \%$ were obtained, showing the wide scope of the ADH (S)@NITQ-2 biocatalyst. When the reduction of 2-octanone was performed with the immobilized enantiocomplementary enzyme (ADH(R)@NITQ-2), NADPH dependent, (entry 1), yield and enantioselectivity to (R)-2-octanol was also very high although longer reaction time was required.

Table 2. Reduction of different ketones using the ADH@NITQ-2 as biocatalyst.

\begin{tabular}{|c|c|c|c|c|c|}
\hline Entry & Substrate & ADH & $\begin{array}{l}\text { time } \\
\text { (h) }\end{array}$ & $\begin{array}{c}\text { Conversion } \\
\text { (Selectivity) } \\
(\%)\end{array}$ & $\begin{array}{l}\text { ee } \\
(\%)\end{array}$ \\
\hline \multirow{2}{*}{1} & & $\mathrm{~s}$ & 1 & $99(100)$ & $>99$ \\
\hline & & $\mathrm{R}^{\mathrm{a}}$ & 6.5 & $98(100)$ & $>99$ \\
\hline \multirow{2}{*}{2} & & $\mathrm{~S}$ & 1.5 & $89(100)$ & \multirow{2}{*}{$>99$} \\
\hline & & & 2 & $99(100)$ & \\
\hline 3 & & $\mathrm{~s}$ & 1 & $99(100)$ & $>99$ \\
\hline 4 & & $\mathrm{~s}$ & 1.5 & $99(100)$ & $>99$ \\
\hline 5 & & $\mathrm{~S}$ & 1.5 & $99(100)$ & $>90$ \\
\hline 6 & & $\mathrm{~s}$ & 2 & $56(100)$ & $>99$ \\
\hline \multirow{2}{*}{7} & & \multirow{2}{*}{$\mathrm{s}$} & 2 & $89(100)$ & \multirow{2}{*}{$>99$} \\
\hline & & & 4 & $95(100)$ & \\
\hline
\end{tabular}

Reaction Conditions: ADH(S)@NITQ-2 (208.6 mg), ketone $0.3 \mathrm{mmol}(30 \mathrm{mM})$, $\mathrm{NAD}^{+}, 0.03 \mathrm{mmol}$ (molar ratio substrate/cofactor $=10$ ), in $10 \mathrm{~mL}$ of solvent (Isopropanol/phosphate buffer solution, $\mathrm{pH} 7,(50 / 50 \mathrm{v} / \mathrm{v})$, at $25{ }^{\circ} \mathrm{C}$. ${ }^{a} \mathrm{ADH}(\mathrm{R}) @ \mathrm{NITQ}-2$ (208.6 mg), ketone $0.3 \mathrm{mmol}(30 \mathrm{mM}), \mathrm{NADP}^{+}, 0.03 \mathrm{mmol}$, in $10 \mathrm{~mL}$ of solvent (Isopropanol/phosphate buffer solution $\mathrm{pH} 7,1 \mathrm{mM} \mathrm{MgCl}_{2}(50 / 50$ $\mathrm{v} / \mathrm{v})$, at $25^{\circ} \mathrm{C}$.

\section{Enzymatic reduction of prochiral ketone in a fixed bed reactor}

Owing to the high activity showed by the ADH@NITQ-2 in batch mode, and following our initial objective, we performed the reduction of the prochiral ketone in a flow reactor. For doing that the ADH(S)@NITQ-2 (208.6 mg) was diluted with silica $1.8 \mathrm{~g} \mathrm{\textrm {SiO } _ { 2 }}$ and packed in a stainless steel reactor coupled with a peristaltic pump for feeding 2-octanone, the cofactor (in a substrate/ cofactor molar ratio of 10 ) and as solvent a mixture of isopropanol/phosphate buffer $\mathrm{pH} 7,100 \mathrm{mM} \mathrm{(50/50}$ $\mathrm{v} / \mathrm{v})$. Temperature was fixed at room temperature, and the contact time was evaluated keeping constant the flow and increasing the amount of 2-octanone. As we can observe (Figure S5 and Table S3) the conversion was maintained 90 \% at contact time above $1.3 \mathrm{~h}$. For a contact time of $2 \mathrm{~h}$ a conversion of $96 \%$ is already achieved, being the selectivity to (S)-2-octanol maintained at $\sim 100 \%$.

Then, we selected a contact time of $1.3 \mathrm{~h}$ to check the stability of the enzymatic derivative. As we can be seen in Figure 1, the 
conversion of 2-octanone (90\%) could be maintained during $24 \mathrm{~h}$ of operation, showing that deactivation does not occur in the studied period. In Figure 2 is showed that using a contact time of $4 \mathrm{~h}$ (that correspond to WHSV of $0.25 \mathrm{~h}^{-1}$ ) the conversion of 2-octanone was maintained to $97 \%$ during $100 \mathrm{~h}$ without deactivation. In fact, the reactor was kept under operation during 16 days, and no deactivation of the catalytic system was observed. Similar data were obtained using the ADH(R)@NITQ-2, obtaining in this case (R)-2-octanol with 100 $\%$ selectivity.

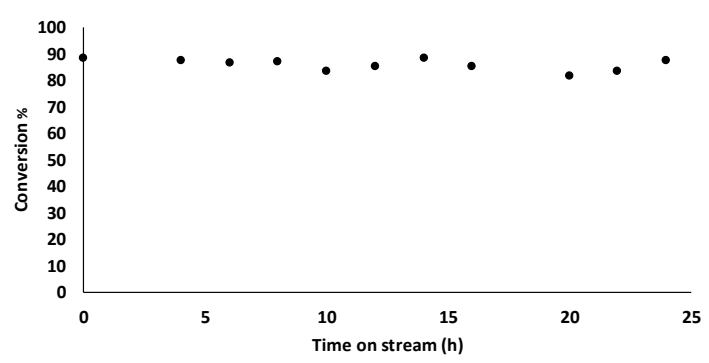

Figure 1. Evaluation of the stability of the reactor at contact time of $1.3 \mathrm{~h}$ for the reduction of 2-octanone to (S)-2-octanol. Reaction conditions: ADH(S)@NITQ-2 (208.6 $\mathrm{mg}), 2$-octanone $(94 \mathrm{mmol} / \mathrm{L}), \mathrm{NAD}^{+}(9,4 \mathrm{mmol} / \mathrm{L})$, solvent (Isopropanol/phosphate buffer solution $\mathrm{pH} 7(50 / 50 \mathrm{v} / \mathrm{v})$, flow $0.55 \mathrm{~mL} / \mathrm{h} 25^{\circ} \mathrm{C}$

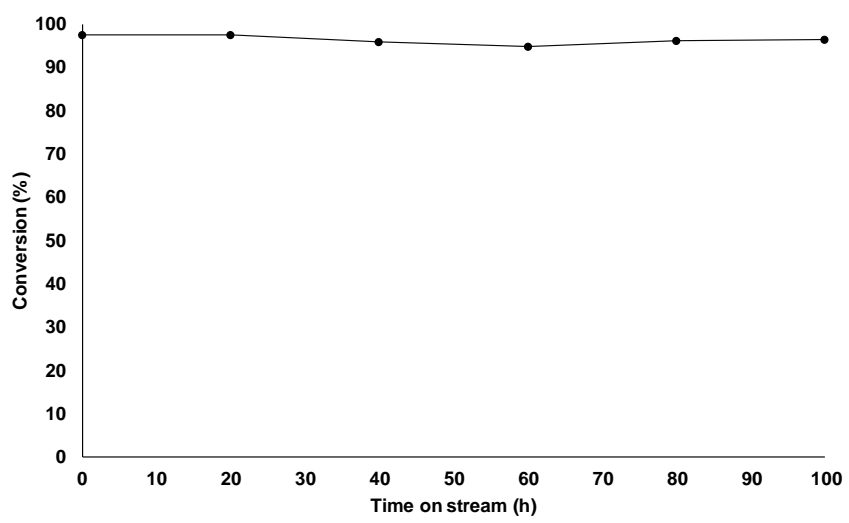

Figure 2. Results of the reduction of 2-octanone into (S)-2-octanol in continuous reactor using ADH(S)@NITQ-2 as biocatalyst. Reaction conditions: ADH(S)@NITQ-2 (208.6 mg), 2-octanone (30 mmol/L), NAD+ (3 mmol/L), solvent (Isopropanol/phosphate buffer solution $\mathrm{pH} 7(50 / 50 \mathrm{v} / \mathrm{v})$, flow $0.55 \mathrm{~mL} / \mathrm{h}, 25^{\circ} \mathrm{C}$.

\section{Oxidation of racemic alcohols into prochiral ketones by Oppenauer reaction in batch mode}

Up to now, we have showed that ADH immobilized on NITQ-2 is an active and stable biocatalyst to perform the steroselective reduction of prochiral ketones into the corresponding enantiopure alcohols. Then, the next step was to check the possibility to perform the oxidation of racemic mixtures of alcohols into prochiral ketones using acetone as hydrogen acceptor that will give isopropanol that will be later used for the enzymatic step, through the Oppenauer oxidation using Zr-Beta zeolite as Lewis acid catalyst. We selected first, the oxidation of 2-octanol using an excess of acetone (acetone/2-octanol molar ratio of 51 ) as the reaction model. The reaction was performed in batch mode at $50{ }^{\circ} \mathrm{C}$ in the presence of Zr-Beta as catalyst. As can be observed in Figure S6, the catalyst performs the oxidation selectively, achieving practically total conversion of the rac-2-octanol with $100 \%$ selectivity to 2-octanone.

Then, the scope of the reaction was tested with a variety of secondary alcohols of different structure. As can be seen in Table 3, the Zr-Beta catalyst performs the reaction with excellent results in all cases. However, depending on the structure of the rac-alcohol, the reaction temperature had to be adjusted in order to achieve high conversion although the selectivity was $100 \%$ in all cases.

Table 3. Reduction of different ketones using the ADH@NITQ2 as biocatalyst.

Entry

Reaction conditions: $\mathrm{Zr}$-Beta $(32 \mathrm{mg})$, alcohol $(0.4 \mathrm{mmol})$, acetone $(1.5 \mathrm{~mL}, 20.4 \mathrm{mmol})$, $20 \mathrm{~h},{ }^{\text {a }}$ at $50^{\circ} \mathrm{C}$. ${ }^{\text {b }}$ at $80^{\circ} \mathrm{C}$

\section{Oxidation of racemic alcohol in a fixed bed reactor}

For the experiments in flow reactor, $304 \mathrm{mg}$ of $\mathrm{Zr}$-Beta zeolite

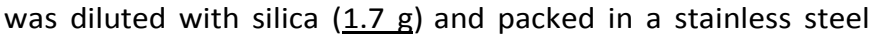
reactor coupled with an electric heater controller and a peristaltic pump for feeding the reactor with a solution of rac2-octanol in acetone and maintaining the temperature at 50 ${ }^{\circ} \mathrm{C}$. The contact time was evaluated by varying the concentration of 2-octanol in the feed while the flow was maintained at $0.5 \mathrm{~mL} / \mathrm{h}$. As we can be seen in Figure $\mathrm{S} 7$ the conversion could be maintained very high (95-98\%) with 100 $\%$ selectivity.

The catalyst stability was evaluated using the contact time of $25 \mathrm{~h}$ (that correspond to WHSV of $0.04 \mathrm{~h}^{-1}$ ), and as can be seen in Figure 3, the catalytic system was stable for $100 \mathrm{~h}$ of operation, being the average conversion of $98 \%$ with $100 \%$ selectivity to the prochiral ketone. 


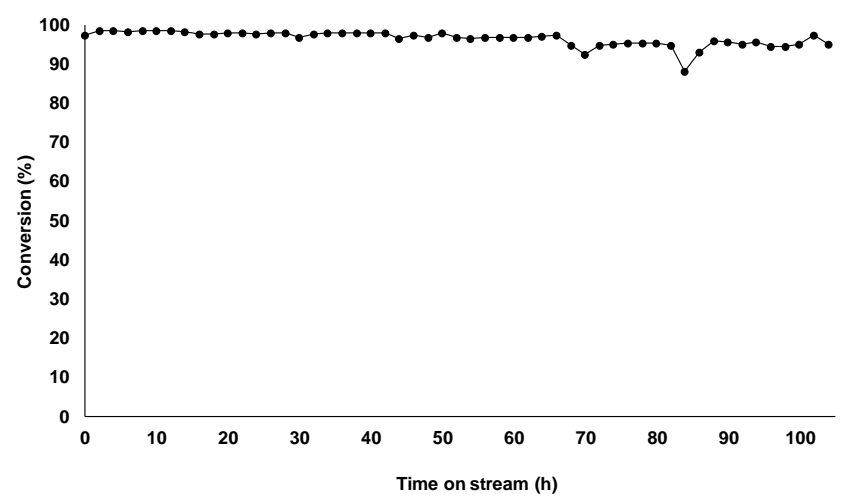

Figure 3. Evaluation of oxidation of rac-2-octanol in continuos reactor. Reaction conditions: Zr-Beta (304 mg), acetone (10 mL, $136 \mathrm{mmol}$ ), 2-octanol $191 \mathrm{mmol} / \mathrm{L}$, flow $0.5 \mathrm{~mL} / \mathrm{h}$ at $50^{\circ} \mathrm{C}$

\section{Coupling Oxidation-Reduction flow reactors}

To explore the efficacy of our proposal for deracemization of secondary alcohols, both steps were coupled in a continuous flow reactor with two catalytic beds. Thus, in a first bed, ZrBeta zeolite was placed and the reactor was fed with a solution of rac-2-octanol in acetone (191 $\mathrm{mmol} / \mathrm{L})$ using a contact time of $25 \mathrm{~h}\left(\mathrm{WHSV} 0.04 \mathrm{~h}^{-1}\right.$ ) flow $0.5 \mathrm{~mL} / \mathrm{h}$, while the temperature was maintained at $50{ }^{\circ} \mathrm{C}$. With an intermediate addition of the cofactor and solvent isopropanol/phosphate buffer $\mathrm{pH} 7,100$ $\mathrm{mM}(50 / 50 \mathrm{v} / \mathrm{v})$, the flow coming out from the first catalytic bed went through the second catalytic bed where the ADH(S)@NITQ-2 was placed. The second catalytic bed was maintained at $25^{\circ} \mathrm{C}$, and the contact time was $4 \mathrm{~h}$ (WHSV 0.25 $\mathrm{h}^{-1}$ ). However, under these conditions (entry 1 , Table 4) the reduction of 2-octanone was decreased to $70 \%$. This was attributed to the presence of acetone in the feed, coming to the enzymatic bed and which reduction competes with the reduction of 2-octanone. To check that, we performed additional experiments where acetone was partially or totally eliminated from the feed going into the second reactor. As can be seen in Table 4, when the amount of acetone was reduced (entry 2) or removed (entry 3 ) from the feed to the second catalytic bed, $96 \%$ conversion with $99 \%$ ee to (S)-2-octanol was achieved. In good agreement with the results presented above in Figure 2, the catalytic activity was maintained for at least $40 \mathrm{~h}$ without observing any deactivation (Figure 4).

Table 4. Effect of the concentration of acetone on the reduction process

\begin{tabular}{ccc}
\hline Entry & Acetone (\%)(v/v) & Conversion of 2-octanone(\%) \\
\hline 1 & 16 & 70 \\
2 & 8 & 79 \\
3 & - & 96 \\
\hline
\end{tabular}

Reaction conditions: (First step) Oxidation reaction of racemic 2-octanol in a continuous flow reactor using Zr-Beta (304 mg), 2-octanol $191 \mathrm{mmol} / \mathrm{L}$, flow $0.5 \mathrm{~mL} / \mathrm{h}$ at $50{ }^{\circ} \mathrm{C}$. (Second step) Reduction reaction of prochiral 2-octanone in a continuous-flow reactor using ADH(2)@NITQ-2 (209 mg), 2-octanone $30 \mathrm{mmol} / \mathrm{L}, \mathrm{NAD}^{+} 3 \mathrm{mmol} / \mathrm{L}$ flow $0.55 \mathrm{~mL} / \mathrm{h}$.

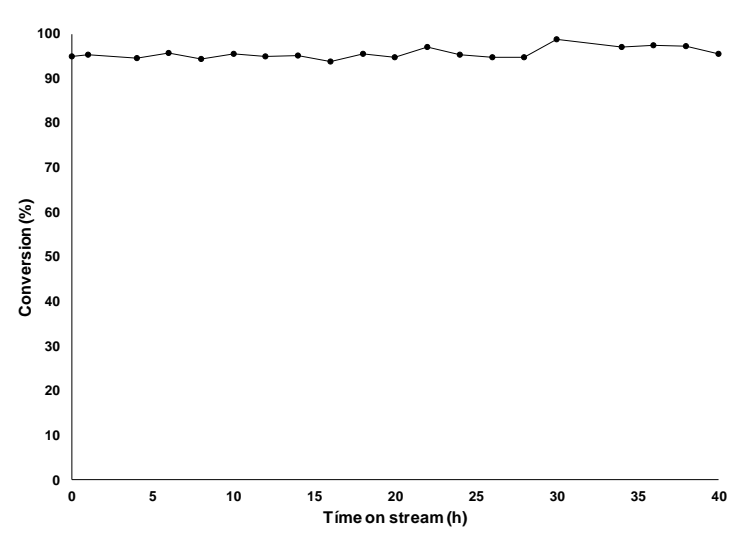

Figure 4. Total yield of (S)-2-octanol obtained from deracemization of rac-2-octanol by the two coupled flow reactors.

Finally, the oxidation-reduction process have been extended to alcohols of different structures, i.e the 2-dodecanol, 1cyclohexylethanol and 4-biphenylmethylcarbinol, also with excellent results (see Figures S8, S9 and S10 respectively).

The results presented above show that it is feasible to couple both steps (oxidation of rac-alcohols with stereoselective reduction of the prochiral ketone intermediate) in a continuous process. Since removal the excess of acetone after the first step is very convenient, we believe that this could be achieved by flash evaporation after the first oxidation reactor. This can be possible without losing the isopropanol formed during the oxidation because the acetone has a boiling point of $56{ }^{\circ} \mathrm{C}$ and the isopropanol $82.5{ }^{\circ} \mathrm{C}$. After that, the acetone could be reused again in the first step of the process (see Scheme 2).

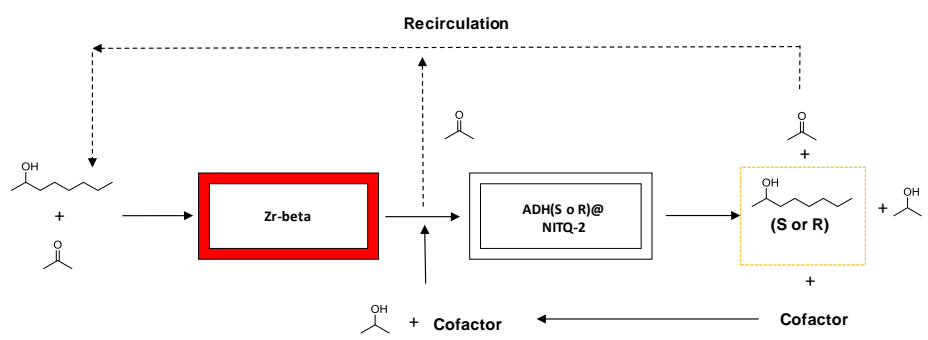

Scheme 2. Possible combination of oxidation-reduction system for an industrial process

\section{Experimental Section}

\section{Materials}

Crude cell extract of prelog Alcohol Dehydrogenases (ADH030) (S) (NADH dependent) and antiPrelog (ADH270) (R) (NADPH dependent) were purchased from Evocatal. 2-Octanol, 2octanone, 1-cyclohexylethanol, 1-cyclohexylethanone, 2pentanol, 2-pentanone, 2-hexanol, 2-hexanone, 2-nonanol, 2nonanone, 2-dodecanol, 2-dodecanone, 4biphenylmethylcarbinol, 4-acetylbiphenyl, the pure chiral compounds ( $R$ and S) 2-octanol, ( $R$ and S) 2-pentanol, ( $R$ and S) 
2-hexanol, (R and S) 2-nonanol and the cofactors NADP ${ }^{+}, \mathrm{NAD}^{+}$ were purchased from Sigma Aldrich. The ( $R$ and S) 2-dodecanol was purchased from Boc Sciences and the ( $R$ and $S)$ 4biphenylmethylcarbinol and ( $R$ and $S)$ 1-cyclohexylethanol were purchased from Enamine Store.

\section{Catalyst preparation and characterization}

\section{Synthesis of the pure silica MWW (MCM-22) zeolite}

The synthesis of pure silica MCM-22 zeolite was performed following the literature. ${ }^{51}$ An example of the procedure for the synthesis of MCM-22 is as follows: $0.95 \mathrm{~g}$ of $\mathrm{NaCl}$ are dissolved in $50.70 \mathrm{~g}$ of a solution $0.42 \mathrm{M}$ of $\mathrm{N}, \mathrm{N}, \mathrm{N}$-trimethyl-1adamantanamonium hydroxide, previously diluted in $21.33 \mathrm{~g}$ of water. Then, $2.62 \mathrm{~g}$ of hexamethyleneimine are added to this solution, followed by $4.88 \mathrm{~g}$ of silica (Aerosil 200, Degussa) under continuous stirring. The reaction mixture is heated in a Teflon lined stainless steel autoclave at $150{ }^{\circ} \mathrm{C}$ rotated at 60 rpm for 5 days. After filtering, the white solid obtained is washed until $\mathrm{pH}$ was less than 9 , and finally dried at $100{ }^{\circ} \mathrm{C}$.

\section{Preparation of pure silica ITQ-2 zeolite}

The synthesis of the pure silica ITQ-2 zeolite was carried following literature. ${ }^{51}$ Typically, $5 \mathrm{~g}$ of the pure silica MCM-22 zeolite were dispersed in $20 \mathrm{~g}$ of water. Then, $100 \mathrm{~g}$ of an aqueous solution of hexadecyltrimethylammonium hydroxide ( $25 \%$ by weight, $50 \%$ exchange $\mathrm{Br} / \mathrm{OH}$ ), and $30 \mathrm{~g}$ of an aqueous solution of tetrapropylammonium ( $40 \%$ by weight, $30 \%$ exchange $\mathrm{Br} / \mathrm{OH})$ were added. The resulting mixture $(\mathrm{pH}$ 12.5) was heated to $55{ }^{\circ} \mathrm{C}$ and stirred vigorously for $16 \mathrm{~h}$ to facilitate swelling between zeolitic sheets. At this point, the suspension was treated in an ultrasonic bath $(50 \mathrm{~W}, 50 \mathrm{~Hz})$ for $1 \mathrm{~h}$ to disperse the zeolitic sheets. By adding $\mathrm{HCl}(6 \mathrm{M})$, the $\mathrm{pH}$ was decreased to about 3 , to facilitate flocculation of the delaminated solid, which is recovered by centrifugation. Then the solid was washed with distilled water, dried at $60{ }^{\circ} \mathrm{C}$ for 12 $\mathrm{h}$, and calcined at $540{ }^{\circ} \mathrm{C}$, first for $3 \mathrm{~h}$ in $\mathrm{N}_{2}$ atmosphere, and then for $6 \mathrm{~h}$ in air.

\section{Functionalization of the support with amino groups}

The support (zeolite ITQ-2 pure silica) $(500 \mathrm{mg}$ ) was activated at $200{ }^{\circ} \mathrm{C}$ under vacuum for 2 hours. After cooling at room temperature, $50 \mathrm{~mL}$ of anhydrous toluene and $240 \mu \mathrm{L}$ of (3aminopropyl) triethoxysilane were added to the solid and the mixture was refluxed for $24 \mathrm{~h}$ at $120{ }^{\circ} \mathrm{C}$. After this time, the solid was filtered under vacuum and washed with toluene and $\mathrm{n}$-hexane, obtaining the material functionalized with amino groups that were labelled as NITQ-2. ${ }^{56,60}$

\section{Preparation of Zr-Beta zeolite}

Nanocrystalline zeolite Beta seeds were synthesized following the procedure described in the bibliography. ${ }^{61,62} \mathrm{~A}$ synthesis gel of molar composition 1.0 SiO2:0.56 TEAOH:0.02 Al2O3: 6.5 $\mathrm{H} 2 \mathrm{O}$ crystallized in a Teflon-lined stainless steel autoclave at $140{ }^{\circ} \mathrm{C}$ for $72 \mathrm{~h}$. The product was separated by centrifugation, washed with deionized water, and dried in air at $100{ }^{\circ} \mathrm{C}$. One gram of the as-made sample was treated with $50 \mathrm{~mL}$ of $6 \mathrm{M}$ $\mathrm{HNO} 3$ at $80{ }^{\circ} \mathrm{C}$ for $24 \mathrm{~h}$ to remove the aluminium. The solid was recovered by filtration, washed with deionized water, and dried at $100{ }^{\circ} \mathrm{C}$.

The synthesis of zeolite $\mathrm{Zr}$-Beta was done according with the bibliography. ${ }^{30,63}$ Typically, Al-free Zr-Beta zeolite was synthesized in a fluoride medium. Tetraethylorthosilicate (TEOS) was hydrolyzed in an aqueous solution of $35 \%$ tetraethylammonium hydroxide (TEAOH) under stirring. A solution of $\mathrm{ZrOCl} 2 \cdot 8 \mathrm{H}_{2} \mathrm{O}$ in water was added and the mixture was stirred until the ethanol formed by hydrolysis of TEOS was evaporated. HF was added to the clear solution and a thick paste was formed. Finally, an aqueous suspension of the dealuminated zeolite Beta seeds was added. The final gel composition was $1.0 \mathrm{SiO}_{2}$ : $0.008 \mathrm{ZrO}_{2}$ : $0.54 \mathrm{TEAOH}: 7.5 \mathrm{H}_{2} \mathrm{O}$ : $0.54 \mathrm{HF}$. Crystallization was carried out in a Teflon-lined stainless steel autoclave at $140{ }^{\circ} \mathrm{C}$ for 14 days. The solid product obtained was filtered, washed with deionized water, dried at $100{ }^{\circ} \mathrm{C}$ and calcined at $580^{\circ} \mathrm{C}$ for $3 \mathrm{~h}$. The amount of $\mathrm{Zr}$ ( $1 \% \mathrm{wt}$ ) on the catalysts was measured by ICP AES analysis, the Brunauer-Emmett-Teller surface area was determined showing that the zeolite has $475 \mathrm{~m}^{2} / \mathrm{g}$ and the micropore volume 0.22 $\mathrm{m}^{3} / \mathrm{g}$.

\section{Immobilization of Alcohol dehydrogenase}

The immobilization of the enzyme $A D H(S)$ and $A D H(R)$ was performed as follows: $10 \mathrm{mg}$ of $\mathrm{ADH}$ ( $\mathrm{R}$ or $\mathrm{S}$ ) was dissolved in 5 $\mathrm{mL}$ of phosphate buffer solution $100 \mathrm{mM}$ (PBS) $\mathrm{pH}=5.5$, subsequently, $200 \mathrm{mg}$ of NITQ-2 was added and left in closed flask under gentle agitation for 24 hours. After this time, to determine the amount of protein immobilized, the protein in the supernatant was analyzed by bicinchoninic acid protein test. To do that, $2 \mathrm{~mL}$ of the bicinchoninic acid test solution was added to $0.1 \mathrm{~mL}$ sample and incubated 30 minutes at 37 ${ }^{\circ} \mathrm{C}$ and then the absorbance at $\lambda_{562 \mathrm{~nm}}$ was measured. ${ }^{64}$ Finally, the biocatalyst was recovered by centrifugation, washed thoroughly and stored at $4{ }^{\circ} \mathrm{C}$.

\section{Catalytic Experiments}

\section{Biocatalyst reactions in batch mode}

Alcohol dehydrogenase reactions were done by incubating the immobilized enzyme ADH(S)@NITQ-2 with the ketone (2octanone) $(0.3 \mathrm{mmol})(30 \mathrm{mM})$, the cofactor $\left(\mathrm{NAD}^{+}\right)$(molar ratio substrate/cofactor $=10)$, in $10 \mathrm{~mL}$ of solvent (Isopropanol/phosphate buffer solution, pH 7, $100 \mathrm{mM}$ ) (50/50 $\mathrm{v} / \mathrm{v})$, at $25{ }^{\circ} \mathrm{C}$ while stirring at $250 \mathrm{rpm}$. For ADH(R)@NITQ-2 reactions, the cofactor used was $\left(\mathrm{NADP}^{+}\right)$in a molar ratio substrate/cofactor $=10$, in $10 \mathrm{~mL}$ of solvent (Isopropanol/phosphate buffer solution, pH 7, $100 \mathrm{mM}$ and $\mathrm{MgCl} 21 \mathrm{mM}(50 / 50 \mathrm{v} / \mathrm{v})$. After reaction, the enzymatic derivative was separated from the mixture by centrifugation at $6000 \mathrm{rpm}$ during 5 minutes, and washed with phosphate buffer ( $\mathrm{pH}$ 7) thoroughly and stored at $4{ }^{\circ} \mathrm{C}$ until use. It is interesting to point out that in all cases, and for economic reasons, we used the cofactor in the oxidized form (NAD+ and 
NADP+) which in the presence of isopropanol and ADH is rapidly reduced into the required cofactor (NADH or NADPH). The reaction mixture was extracted using $n$-hexane and dried with anhydrous MgSO4. Then organic phase was analysed on a Varian 3900 gas chromatograph equipped with a capillary column HP-5 $(30 \mathrm{~m} \times 0.25 \mathrm{~mm} \times 0.25 \mu \mathrm{m})$ and flame ionization detector (FID). Dodecane was used as external standard. The molar balance was in all cases $>97 \%$.

The identification of the products was carried out by GC-MS on an Agilent 5973 Network Mass selective Detector equipped with a capillary column HP5-MS Ultrainert $(30 \mathrm{~m} \times 0.25 \mathrm{~mm} \times$ $0.25 \mu \mathrm{m})$ and FID detector. The retention time and GC-MS spectra of the alcohols produced were compared with that of the pure commercial alcohols.

Enantiomeric excess of the secondary alcohol was determined on a Varian 3900 gas chromatograph equipped with a (Supelco $\beta$-Dex225 $30 \mathrm{~m} \times 0.25 \mathrm{~mm} \times 0.25 \mu \mathrm{m}$ ) and FID detector, previous derivatization of the alcohols with trifluoroacetic anhydride following the method described in the literature. ${ }^{65}$ Typically, in a solution of alcohol $(5 \mathrm{mmol})$, triethylamine (6 $\mathrm{mmol}$ ), and 4-(dimethylamino)pyridine $(0.5 \mathrm{mmol})$ in $\mathrm{CH}_{2} \mathrm{Cl}_{2}$ (5 $\mathrm{mL}$ ) was added trifluoroacetic anhydride $(6.2 \mathrm{mmol})$ at $0{ }^{\circ} \mathrm{C}$. After the mixture was stirred at $0{ }^{\circ} \mathrm{C}$ for $2 \mathrm{~h}$ and then at room temperature for $2 \mathrm{~h}, \mathrm{H}_{2} \mathrm{O}$ was added to the mixture and organic phase was separated. The aqueous phase was extracted with $\mathrm{CH}_{2} \mathrm{Cl}_{2}$ (four times) and the combined organic phase was dried over MgSO4 and analysed by GC with Supelco $\beta$-Dex column. The identity of the chiral products was verified by comparing the retention times with the pure chiral commercial alcohols, under the same derivatization conditions.

\section{Activity recovery determination}

Activity recovery was determined according to literature, ${ }^{57} 2$ octanone $(30 \mathrm{mM})$, the cofactor $\left(\mathrm{NAD}^{+}\right) 3 \mathrm{mM}$, in $10 \mathrm{~mL}$ of solvent (Isopropanol/phosphate buffer solution, $\mathrm{pH} \mathrm{7,} 100$ $\mathrm{mM})(50 / 50 \mathrm{v} / \mathrm{v})$ was submitted to reduction using $10 \mathrm{mg}$ of free $A D H(S)$. The activity was measured and expressed as the rate of S-2-octanol produced $\left(\mu \mathrm{mol} \cdot \mathrm{min}^{-1}\right)$. Then, $10 \mathrm{mg}$ of $\mathrm{ADH}(\mathrm{S})$ were put in contact with $200 \mathrm{mg}$ of NITQ-2 during 24 hours as was described above. After that the solid was recovered by centrifugation and the activity of the total amount of immobilized enzyme was determined under the same conditions as the free enzyme. Activity recovery is expressed as a percentage: (activity of immobilized enzyme/activity of free enzyme) x 100 .

\section{Determination of catalytic activity in function of $\mathrm{pH}$ and thermal stability}

The effect of the $\mathrm{pH}$ on the catalytic activity of the ADH-S free and immobilized form were determined by incubating the enzyme during 1 hour in the presence of the substrate (2octanone) in the same conditions that we describe above, in a $\mathrm{pH}$ range from 5.5 to 10 . The thermal stability of the enzyme was determined by heating during 1 hour the free and the immobilized ADH-S at temperatures between 25 and $55{ }^{\circ} \mathrm{C}$.
Subsequently the cofactor and the substrate (2-octanone) were added and the reaction was carried out under the reaction conditions describe above.

\section{Oxidation of racemic alcohols using $\mathrm{Zr}$-Beta in batch mode}

Typically, in a glass reactor were placed $0.4 \mathrm{mmol}$ of (rac)-2octanol in $1.5 \mathrm{~mL}$ of acetone (hlpc grade) and $32 \mathrm{mg}$ of $\mathrm{Zr}$-Beta zeolite ( $1 \mathrm{wt} \%$ ). The solution was heated at $50{ }^{\circ} \mathrm{C}$ during $24 \mathrm{~h}$ while stirring at $750 \mathrm{rpm}$. Finally, the catalyst was removed by centrifugation $6000 \mathrm{rpm}$ during $5 \mathrm{~min}$. The reaction was followed taking samples at regular periods that were analysed by Varian 3900 gas chromatograph equipped with a capillary column HP-5 (30 m $\times 0.25 \mathrm{~mm} \times 0.25 \mu \mathrm{m})$ and FID detector. Dodecane was used as external standard. The molar balance in all cases was $>96 \%$. The identification of the products was carried out by GC-MS on an Agilent 5973 Network Mass selective Detector equipped with a capillary column HP5-MS Ultrainert $(30 \mathrm{~m} \times 0.25 \mathrm{~mm} \times 0.25 \mu \mathrm{m})$ and FID detector. The retention time and GC-MS spectra of the ketones produced were compared with that of the pure commercial ketones.

\section{Enzymatic reduction of prochiral ketone in a fixed bed reactor}

The experiments in flow reactor were carried out as follows: a dry sample of ADH@NITQ2 (209 mg) was diluted with silica $\left(\mathrm{SiO}_{2} \geq 0.25 \mu \mathrm{m}, 1.8 \mathrm{~g}\right)$ and packed in a stainless steel reactor (diameter $1 \mathrm{~mm}, 35 \mathrm{~mm}$ height). The catalyst dilution with inert solid particle, having the same size of the catalytic particles, reduces the local hot-spots and improves the temperature distribution along the catalytic bed. The dilution of the catalyst was taken following the literature, ${ }^{66}$ where is recommended that the volume of the bed (catalyst plus inert) has to fit in a range depending on the diameter and length of the reactor used. Temperature was fixed at room temperature for all experiments, and the reactor was coupled with a peristaltic pump for feeding. To evaluate the contact time increasing concentrations of 2-octanone in isopropanol/phosphate buffer $(\mathrm{pH} \mathrm{7,100} \mathrm{mM)} \mathrm{(50/50} \mathrm{v/v)}$ were used as feed, while keeping constant the temperature, the flow rate $\left(0.55 \mathrm{~mL} / \mathrm{h}\right.$ ), and the molar ratio (substrate/NAD ${ }^{+}$ $=10)$. The contact time has been calculated as the inverse of Space velocity WSHV $\left(h^{-1}\right)$ which is defined as: WSHV $\left(h^{-}\right.$ 1)=limiting reactant $\left(\mathrm{g} \cdot \mathrm{h}^{-1}\right) / \mathrm{gram}$ of catalyst.

\section{Oxidation of racemic alcohol in a fixed bed reactor}

The continuous experiments were carry out as follows: $304 \mathrm{mg}$ of dry catalyst $\mathrm{Zr}$-Beta $(0.2-0.4 \mu \mathrm{m})$ was diluted with silica $\left(\mathrm{SiO}_{2}\right.$ $\geq 0.25 \mu \mathrm{m}, 1.7 \mathrm{~g}$ ) and packed in a stainless steel reactor (diameter $1 \mathrm{~mm}, 35 \mathrm{~mm}$ height) coupled with an electric heater controller and a peristaltic pump for feeding the reactor. The temperature was fixed at $50{ }^{\circ} \mathrm{C}$ and stability and contact time conditions were evaluated. For this propose, increasing concentrations of 2-octanol in acetone were used as feed, while keeping constant the flow rate $(0.5 \mathrm{~mL} / \mathrm{h})$.

\section{Coupling Oxidation-Reduction in a flow reactor}


The coupling of both reactors were carried out as follows: the oxidation of 2-octanol was done using $304 \mathrm{mg}$ of dry catalyst Zr-Beta $(0.2-0.4 \mu \mathrm{m})$ diluted with silica $\left(\mathrm{SiO}_{2} \geq 0.25 \mu \mathrm{m} ; 1.7 \mathrm{~g}\right)$ and packed in a stainless steel reactor (diameter $1 \mathrm{~mm}, 35 \mathrm{~mm}$ height) coupled with an electric heater controller and a peristaltic pump for feeding the reactor, the temperature was fixed at $50{ }^{\circ} \mathrm{C}$. The reactor was feed with a solution of 2octanol in acetone $(191 \mathrm{mmol} / \mathrm{L})$ with a flow of $0.5 \mathrm{~mL} / \mathrm{h}$ and contact time $25 \mathrm{~h}$. After that, the solution of 2-octanone obtained after the first reactor $(10 \mathrm{~mL})$ was diluted with isopropanol/phosphate buffer $(\mathrm{pH} \mathrm{7,} 100 \mathrm{mM})(50 / 50 \mathrm{v} / \mathrm{v})$ until a volume of $62 \mathrm{~mL}$ (which contains $16 \mathrm{v} / \mathrm{v} \%$ acetone) (Entry 1, Table 4). To this solution of 2-octanone (30 mM) the cofactor $\left(\mathrm{NAD}^{+}\right)$( $3 \mathrm{mM}$ ) was added and used for feeding the second reactor (where was the ADH(S)@NITQ-2) at a flow of $0.55 \mathrm{~mL} / \mathrm{h}$.

In a second experiment, the amount of acetone of the solution obtained after the first reactor was reduced by evaporation up to $8 \mathrm{v} / \mathrm{v} \%$, and then proceeded as above (entry 2 Table 4 ). Finally, in the last experiment the acetone was completely evaporated from the solution obtained from the first reactor and proceeded as above (entry 3, Table 4).

\section{Analytical methods}

Infrared analysis of the support was performed with a IR Vertex Burker DTGS (Detector), and a conventional quartz infrared cell Quartz KR55 windows connected to a vacuum dosing system. The samples were pressed into self-supporting pellets and treated under vacuum $\left(10^{-4}\right.$ to $\left.10^{-5} \mathrm{~Pa}\right)$ at $400^{\circ} \mathrm{C}$ for 24 hours.

The specific surface areas of the supports were calculated by the Brunauer-Emmett-Teller (BET) method by means of nitrogen adsorption at $-196{ }^{\circ} \mathrm{C}$, using an ASAP 2420 (V2.09 J). Nitrogen adsorption isotherms of ITQ-2, NITQ-2 and ADH8.6mg@NITQ-2 are presented in Figures S11-13 respectively, and the pore size distribution of ITQ-2 and ADH8.6mg@NITQ-2 are presented in Figure S14.

Elemental analysis (Table S1) were performed in a Euro EA3000 Elemental Analyzer (EuroVector), using sulfanilamide as reference.

Isoelectronic point of $\mathrm{ADH}(\mathrm{S})$ was determined according with the literature. ${ }^{67}$ Typically, $10 \mathrm{mg} \mathrm{ADH}(\mathrm{S})$ were dissolved in $5 \mathrm{~mL}$ of phosphate buffer $\mathrm{pH}$ from 3 to $7(100 \mathrm{mM})$, then the solutions were stirred at $450 \mathrm{rpm}$ for $1 \mathrm{~h}$ at $50{ }^{\circ} \mathrm{C}$, the precipitated protein was recovered by centrifugation $10 \mathrm{~min}$ at $6000 \mathrm{rpm}$. Finally, the samples were dried at $60^{\circ} \mathrm{C}$ for $24 \mathrm{~h}$ and the amount of precipitated protein was determinate by analytical balance.

The metal contents in the samples and metal leaching were analysed by inductively coupled plasma atomic emission spectroscopy (ICP-AES) using a Varian 715-ES.

\section{Conclusions}

A new process for producing chiral alcohols starting from racemic mixtures has been developed. The process involves two catalytic steps. In the first one, the alcohol is oxidized to a prochiral ketone using acetone as hydrogen acceptor with a very efficient solid $\mathrm{Zr}$-Beta catalyst. In the second step the ketone is stereoselectively reduced with an alcohol dehydrogenase immobilized in a $2 \mathrm{D}$ zeolite. The process can be carried out within two consecutive CSTR reactor system or with a two fixed beds continuous reactor. In both cases conversions above $95 \%$ with $100 \%$ selectivity to the desired $\mathrm{R}$ or $\mathrm{S}$ alcohol is obtained. This combined heterogeneous chemical/enzymatic catalytic process can be applied with excellent results to a large variety of racemic alcohols. The catalyst is very stable and the two beds continuous system has been operated for more than 16 days without deactivation.

\section{Conflicts of interest}

There are no conflicts to declare

\section{Acknowledgements}

The research leading to these results has received funding from the Spanish Ministry of Science, Innovation and Universities through "Severo Ochoa" Excellence Programme (SEV-2016-0683) and the PGC2018-097277-B100(MCIU/AEI/FEDER, UE) project. J.M.C thanks to Universitat Politécnica de Valencia for a predoctoral fellowship.

\section{Notes and references}

1

2
S. Roger A., Chirotechnology: Industrial synthesis of optically active compounds, Marcel Dekker, Inc., New York, 1993.

Y. Okamoto and T. Ikai, Chem. Soc. Rev., 2008, 37, 25932608.

R. Xie, L. Y. Chu and J. G. Deng, Chem. Soc. Rev., 2008, 37, 1243-1263.

Y. Nie, Y. Xu, Q. M. Xiao, Y. Tang, J. Jiang and Z. H. Sun, Biotechnol. Lett., 2005, 27, 23-26.

A. Liese, T. Zelinski, M. R. Kula, H. Kierkels, M. Karutz, U. Kragl and C. Wandrey, J. Mol. Catal. B Enzym., 1998, 4, 9199.

D. Pociecha, M. Glogarová, E. Gorecka and J. Mieczkowski, Phys. Rev. E - Stat. Physics, Plasmas, Fluids, Relat. Interdiscip. Top., 2000, 61, 6674-6677.

L. Xue, D. J. Zhou, L. Tang, X. F. Ji, M. Y. Huang and Y. Y. Jiang, React. Funct. Polym., 2004, 58, 117-121.

Z. Wu, X. Li, F. Li, H. Yue, C. He, F. Xie and Z. Wang, RSC Adv., 2014, 4, 33998-34002.

M. Rachwalski, N. Vermue and F. P. J. T. Rutjes, Chem. Soc. Rev., 2013, 42, 9268-9282.

M. Bakker, A. S. Spruijt, F. van Rantwijk and R. A. Sheldon, Tetrahedron Asymmetry, 2000, 11, 1801-1808. 
C. Kim, J. Lee, J. Cho, Y. Oh, Y. K. Choi, E. Choi, J. Park and M. J. Kim, J. Org. Chem., 2013, 78, 2571-2578. J. H. Lee, K. Han, M. J. Kim and J. Park, European J. Org. Chem., 2010, 999-1015. A. Parvulescu, J. Janssens, J. Vanderleyden and D. De Vos, Top. Catal., 2010, 53, 931-941.

O. Verho and J. E. Bäckvall, J. Am. Chem. Soc., 2015, 137, 3996-4009.

C. C. Gruber, I. Lavandera, K. Faber and W. Kroutil, Adv. Synth. Catal., 2006, 348, 1789-1805.

C. V. Voss, C. C. Gruber and W. Kroutil, Synlett, 2010, 991998.

V. Voss, C. C. Gruber, K. Faber, T. Knaus, P. Macheroux and W. Kroutil, J. Am. Chem. Soc., 2008, 130, 1396913972.

A. Díaz-Rodríguez, N. Ríos-Lombardía, J. H. Sattler, I. Lavandera, V. Gotor-Fernández, W. Kroutil and V. Gotor, Catal. Sci. Technol., 2015, 5, 1443-1446.

K. Kȩdziora, A. Díaz-Rodríguez, I. Lavandera, V. GotorFernández and V. Gotor, Green Chem., 2014, 16, 24482453.

E. Liardo, N. Ríos-Lombardía, F. Morís, J. González-Sabín and F. Rebolledo, European J. Org. Chem., 2018, 2018, 3031-3035.

D. Méndez-Sánchez, J. Mangas-Sánchez, I. Lavandera, V. Gotor and V. Gotor-Fernández, ChemCatChem, 2015, 7, 4016-4020.

H. Gröger and W. Hummel, Curr. Opin. Chem. Biol., 2014, 19, 171-179.

A. Corma, Angew. Chemie - Int. Ed., 2016, 55, 6112-6113. P. J. Kunkeler, B. J. Zuurdeeg, J. C. van der Waal, J. A. van Bokhoven, D. C. Koningsberger and H. van Bekkum, J. Catal., 1998, 180, 234-244.

J. C. van der Waal, E. J. Creyghton, P. J. Kunkeler, K. Tan and H. van Bekkum, Top. Catal., 1997, 4, 261-268.

E. J. Creyghton, S. D. Ganeshie, R. S. Downing and H. van Bekkum, J. Mol. Catal. A Chem., 1997, 115, 457-472.

J. C. van der Waal, K. Tan and H. van Bekkum, Catal. Letters, 1996, 41, 63-67.

A. Corma, M. E. Domine, L. Nemeth and S. Valencia, J. Am. Chem. Soc., 2002, 124, 3194-3195.

A. Corma, M. E. Domine and S. Valencia, J. Catal., 2003, 215, 294-304.

M. Boronat, A. Corma and M. Renz, J. Phys. Chem. B, 2006, 110, 21168-21174.

M. Boronat, A. Corma, M. Renz and P. M. Viruela, Chem. A Eur. J., 2006, 12, 7067-7077.

W. Hussain, D. J. Pollard, M. Truppo and G. J. Lye, J. Mol. Catal. B Enzym., 2008, 55, 19-29.

D. M. Tschaen, L. Abramson, D. Cai, R. Desmond, U. H. Dolling, L. Frey, S. Karady, Y. J. Shi and T. R. Verhoeven, J. Org. Chem., 1995, 60, 4324-4330.

E. Keinan, K. K. Seth and R. Lamed, Ann. NEW YORK Acad. Sci., 1987, 501, 130-149.

W. Hummel, Appl. Microbiol. Biotechnol., 1990, 34, 15-19. D. Metrangolo-Ruiz de Temiño, W. Hartmeier and M. B.
Ansorge-Schumacher, Enzyme Microb. Technol., 2005, 36 3-9.

L. Cao, Carrier-bound Immobilized Enzymes: Principles, Application and Design, Wiley-VCH., 2006.

K. Faber, Biotransformations in Organic Chemistry, New York, Springer B., 1996.

A. I. Benítez-Mateos, M. L. Contente, S. Velasco-Lozano, F. Paradisi and F. López-Gallego, ACS Sustain. Chem. Eng., 2018, 6, 13151-13159.

S. Velasco-Lozano, A. I. Benítez-Mateos and F. LópezGallego, Angew. Chemie - Int. Ed., 2017, 56, 771-775. R. Di Cosimo, J. Mc Auliffe, A. J. Poulose and G. Bohlmann, Chem. Soc. Rev., 2013, 42, 6437-6474.

A. I. Benítez-Mateos, E. San Sebastian, N. Ríos-Lombardía, F. Morís, J. González-Sabín and F. López-Gallego, Chem. - A Eur. J., 2017, 23, 16843-16852.

J. M. Bolivar, L. Wilson, S. A. Ferrarotti, J. M. Guisán, R. Fernández-Lafuente and C. Mateo, J. Biotechnol., 2006, 125, 85-94.

S. Xu, Y. Lu, Z. Jiang and H. Wu, J. Mol. Catal. B Enzym., 2006, 43, 68-73. Younus and S. I. Al-Resayes, Int. J. Biol. Macromol., 2015, 72, 1196-1204.

X. P. Jiang, T. T. Lu, C. H. Liu, X. M. Ling, M. Y. Zhuang, J. X. Zhang and Y. W. Zhang, Int. J. Biol. Macromol., 2016, 88, 917.

M. F. Alam, A. A. Laskar, M. Zubair, U. Baig and H. Younus, J. Mol. Catal. B Enzym., 2015, 119, 78-84. 1213-1220.

M. Dreifke, F. J. Brieler and M. Fröba, ChemCatChem, 2017 9, 1197-1210.

S. Ghannadi, H. Abdizadeh, M. Miroliaei and A. A. Saboury, Ind. Eng. Chem. Res., 2019, 58, 9844-9854.

A. Corma, V. Fornes, S. B. Pergher, T. L. M. Maesen and J. G. Buglass, Nature, 1998, 396, 353-356.

E. M. Gallego, M. T. Portilla, C. Paris, A. León-escamilla, M. Boronat, M. Moliner and A. Corma, Science (80-. )., 2017, 355, 1051-1054.

V. J. Margarit, M. R. Díaz-Rey, M. T. Navarro, C. Martínez and A. Corma, Angew. Chemie - Int. Ed., 2018, 57, 34593463.

H. Y. Luo, V. K. Michaelis, S. Hodges, R. G. Griffin and Y. Román-Leshkov, Chem. Sci., 2015, 6, 6320-6324. J. M. Carceller, J. P. Martínez Galán, R. Monti, J. C. Bassan, M. Filice, S. Iborra, J. Yu and A. Corma, Green Chem., 2019, 21, 839-849.

A. Corma, V. Fornes and F. Rey, Adv. Mater., 2002, 14, 7174.

R. A. Sheldon and S. van Pelt, Chem. Soc. Rev., 2013, 42, 6223-6235.

D. Thiel, D. Doknić and J. Deska, Nat. Commun., 2014, 5, 17.

O. Kniemeyer and J. Heider, Arch. Microbiol., 2001, 176, 129-135. 
60 A. Corma, V. Fornés, J. L. Jordá, F. Rey, R. FernandezLafuente, J. M. Guisan and C. Mateo, Chem. Commun., 2001, 5, 419-420.

61 M. A. Camblor, A. Corma, A. Mifsud, J. Pérez-Pariente and S. Valencia, Prog. Zeolite Microporous Mater. Stud. Surf. Sci. Catal., 1997, 105, 341-348.

62 T. Blasco, M. A. Camblor, A. Corma, P. Esteve, J. M. Guil, A. Martínez, J. A. Perdigón-Melón and S. Valencia, J. Phys. Chem. B, 1998, 102, 75-88.

63 Y. Zhu, G. Chuah and S. Jaenicke, J. Catal., 2004, 227, 1-10.

64 P. K. Smith, R. I. Krohn, G. T. Hermanson, A. K. Mallia, F. H. Gartner, M. D. Provenzano, E. K. Fujimoto, N. M. Goeke, B. J. Olson and D. C. Klenk, Anal. Biochem., 1985, 150, 76-85. P. Xu, P. X. Du, M. H. Zong, N. Li and W. Y. Lou, Sci. Rep., 2016, 6, 1-10.

66 C. Perego and S. Peratello, Catal. Today, 1999, 52, 133145.

67 A. M. Serpa Guerra, G. Hincapié Llano and C. Álvarez López, Prospectiva, 2014, 12, 30-39. 


\section{Supporting Information}

\section{Production of chiral alcohols from racemic mixtures by}

integrated heterogeneous chemoenzymatic catalysis in fixed

\section{bed continuous operation}

J. Miguel Carceller, Maria Mifsud, Maria J. Climent, Sara Iborra*, Avelino Corma*

Instituto de Tecnología Química (UPV-CSIC).

Universitat Politècnica de València

Avda dels Tarongers s/n, 46022, Valencia (Spain)

Fax: (+34) 963877809

E-mail: acorma@itq.upv.es

siborra@itq.upv.es 
Table S1. Elemental analysis of the support

\begin{tabular}{cccc}
\hline Material & $\mathrm{N} \%$ & $\mathrm{H} \%$ & $\mathrm{C} \%$ \\
\hline ITQ-2 & - & 0.92 & 0.31 \\
N-ITQ2 & 2.5 & 2.21 & 9.96 \\
\hline
\end{tabular}

Table S2. Surface area of ITQ-2 zeolite, surface modified NITQ-2 and ADH@NITQ-2 catalyst.

\begin{tabular}{ccc}
\hline Material & BET $\left(\mathrm{m}^{2} / \mathrm{g}\right)$ & $\begin{array}{c}\text { External } \\
\text { surface area } \\
\left(\mathrm{m}^{2} / \mathrm{g}\right)\end{array}$ \\
\hline ITQ-2 & 756 & 592 \\
NITQ-2 & 387 & 347 \\
\hline
\end{tabular}


Table S3. Evaluation of the contact time in flow reactor for the reduction of 2octanone to (S)-2-octanol.

\begin{tabular}{ccc}
\hline $\mathrm{mmol} / \mathrm{L}$ & $\mathrm{CT}(\mathrm{h})$ & $\begin{array}{c}\text { (\%) Conversion } \\
\text { (Selectivity) }\end{array}$ \\
\hline 30 & 4.0 & $97(100)$ \\
60 & 2.0 & $96(100)$ \\
94 & 1.3 & $90(100)$ \\
114 & 1.1 & $85(100)$ \\
160 & 0.8 & $54(100)$
\end{tabular}

Conditions: $\mathrm{ADH}(\mathrm{S}) @ \mathrm{NITQ}-2$ (208.6 mg), NAD+, (molar ratio substrate/cofactor $=10$ ), in $10 \mathrm{~mL}$ of solvent (Isopropanol/phosphate buffer solution $\mathrm{pH} 7100 \mathrm{mM}$ $(50 / 50 \mathrm{v} / \mathrm{v})$, at $25^{\circ} \mathrm{C}$, flow $0.55 \mathrm{~mL} / \mathrm{h}$. 


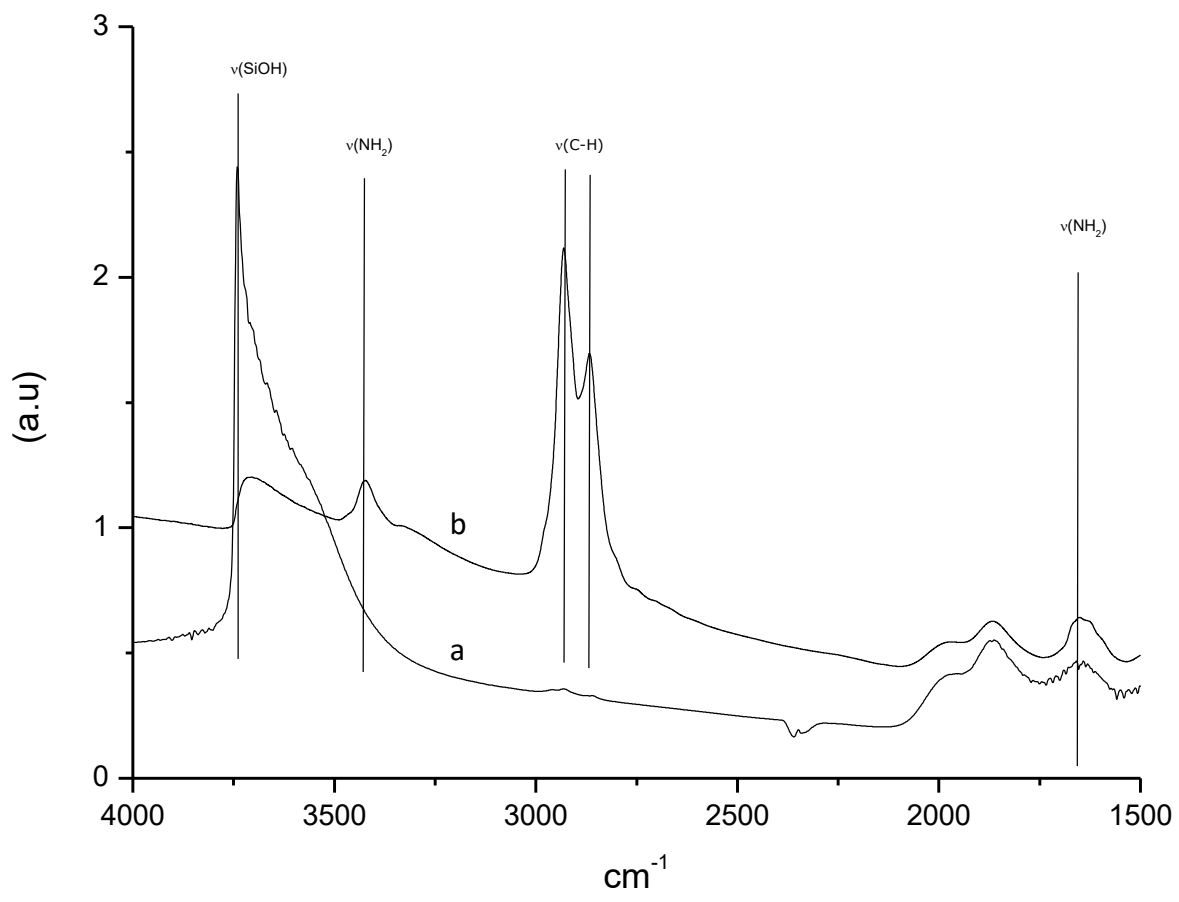

Figure S1. FTIR spectra of ITQ-2 pure silica (a); NITQ-2 (b) 


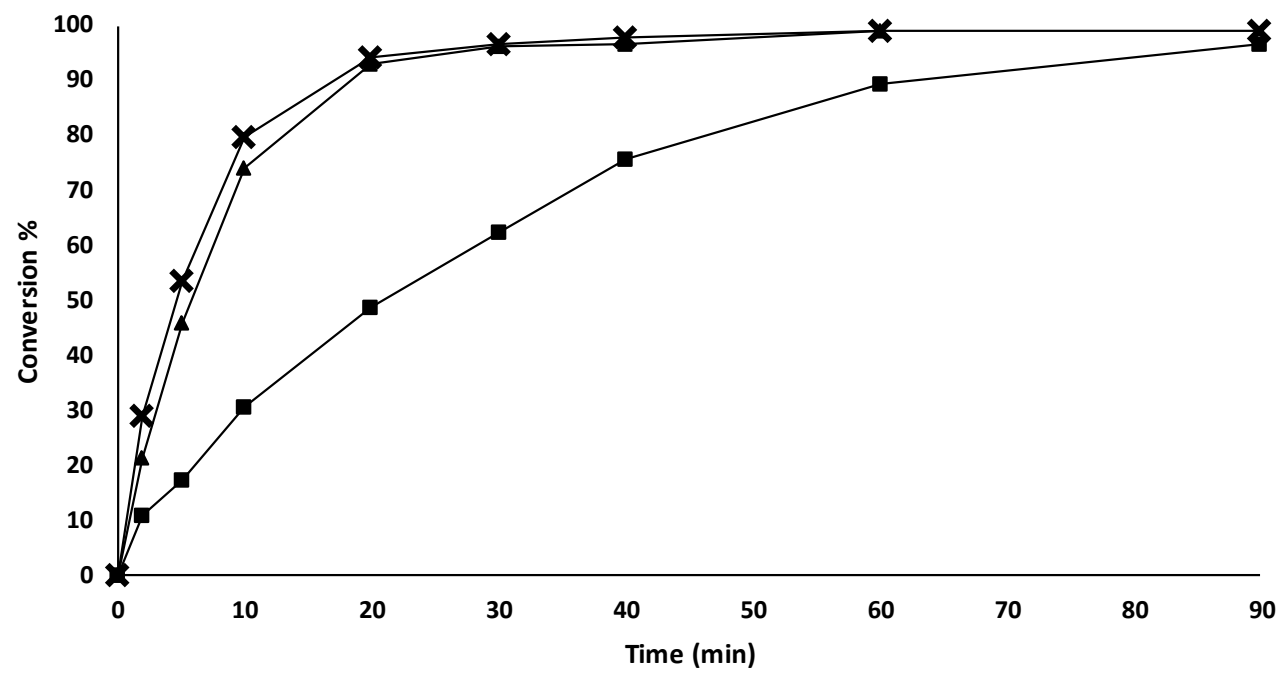

Figure S2. Catalytic activity of ADH(S)@NITQ-2 with different loadings in the conversion of 2-octanone into (S)-2-octanol. (x) ADH8.6mg@NITQ-2, (4) ADH7.5mg@NITQ-2, (•) ADH2.5mg@NITQ-2. Reaction conditions: 2octanone, $0.3 \mathrm{mmol}(30 \mathrm{mM}), \mathrm{NAD}^{+}, 0.03 \mathrm{mmol}$ (molar ratio substrate/cofactor $=10$ ), in $10 \mathrm{~mL}$ of solvent (Isopropanol/phosphate buffer solution pH $7100 \mathrm{mM}$ $(50 / 50 \mathrm{v} / \mathrm{v})$. 


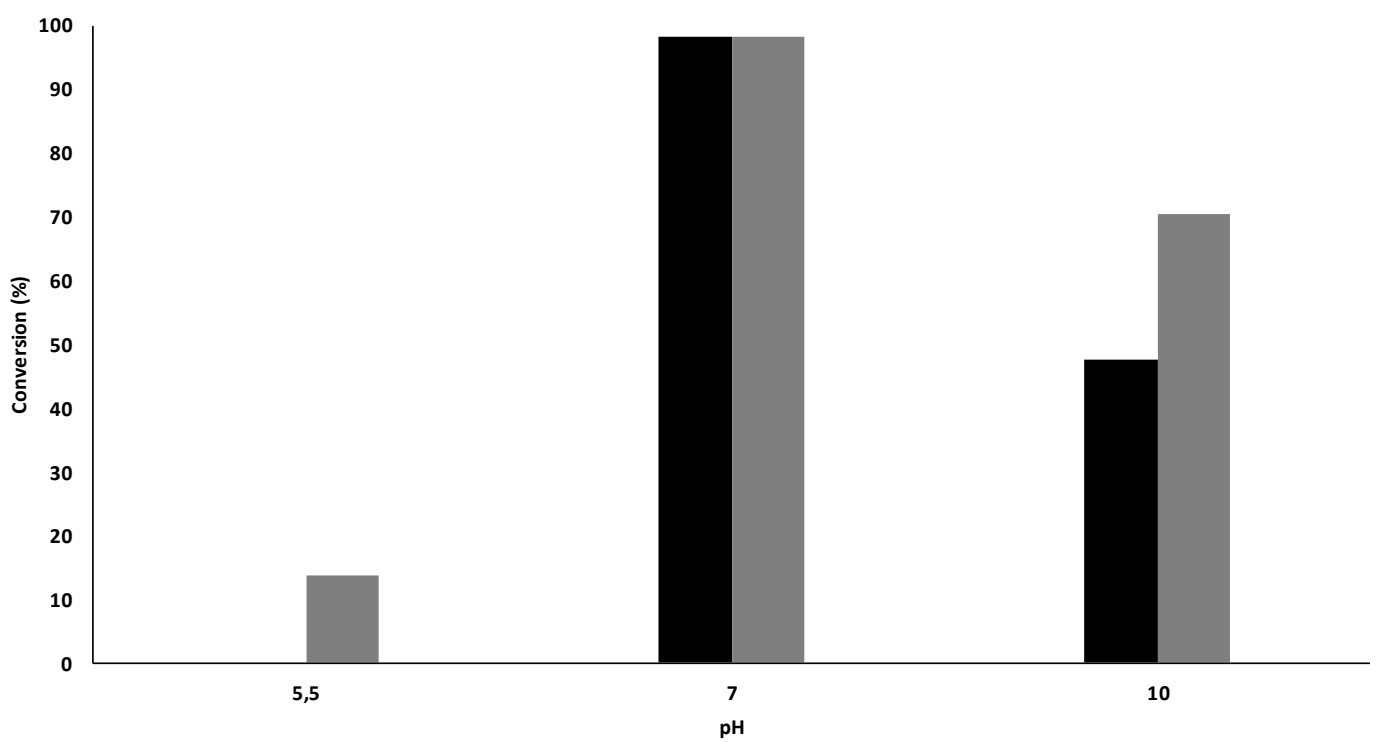

Figure S3. Effect of $\mathrm{pH}$ on the activity of $\mathrm{ADH}$ in the reduction of 2-octanone into (S)-2-octanol. ( $\square) A D H(S)$ free, ( $\square) A D H(S) @ N I T Q-2$. Reaction conditions: ADH(S) (8.6 mg) or ADH(S)@NITQ-2 (208.6 mg), 2-octanone, $0.3 \mathrm{mmol}$ (30 $\mathrm{mM}$ ), NAD+, $0.03 \mathrm{mmol}$ (molar ratio substrate/cofactor $=10$ ), in $10 \mathrm{~mL}$ of solvent (Isopropanol/phosphate buffer solution of pH 5.5, 7 and $10(50 / 50 \mathrm{v} / \mathrm{v}), 1 \mathrm{~h}$, at $25^{\circ} \mathrm{C}$. 


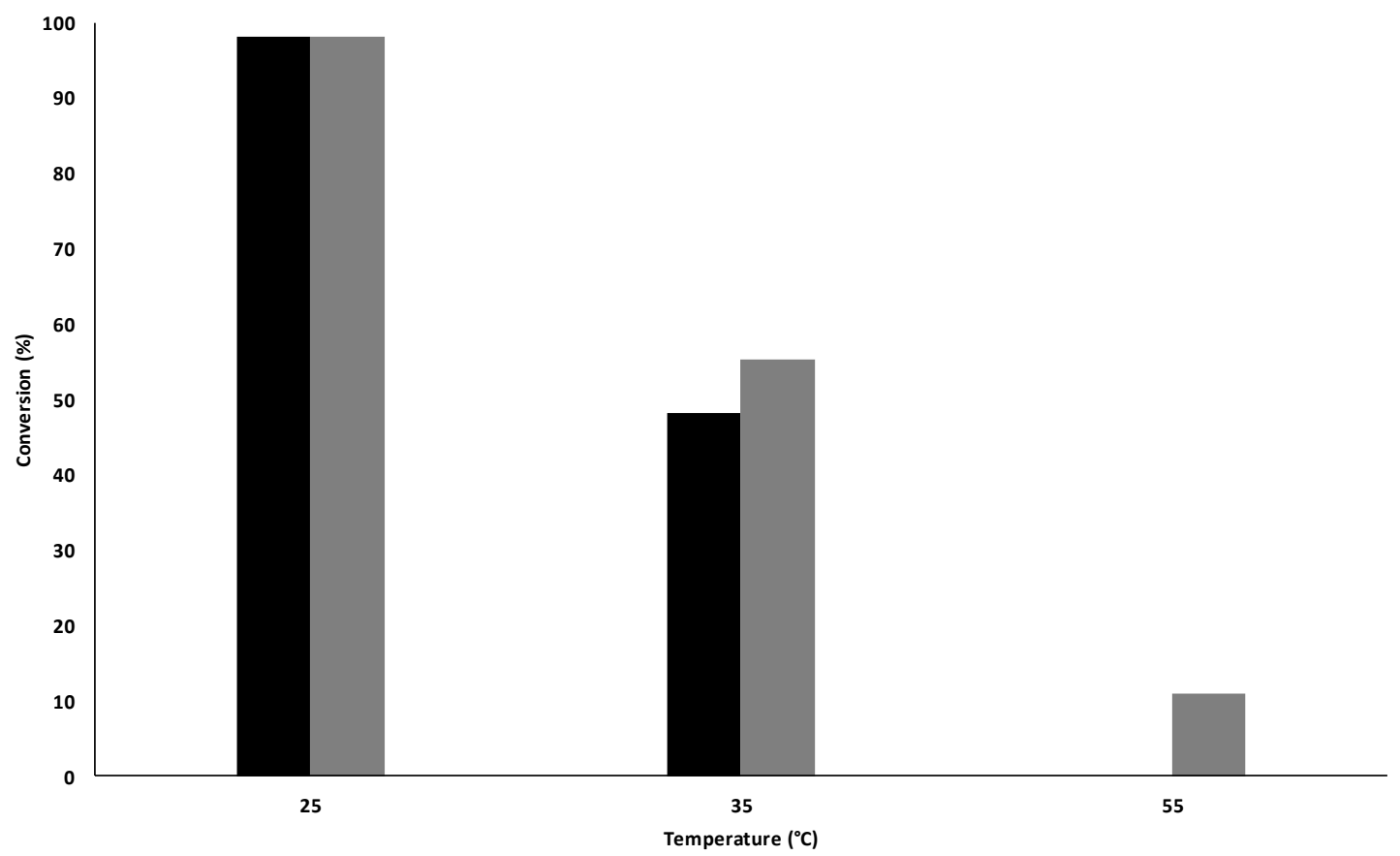

Figure S4. Thermal stability of the immobilized or free enzyme $A D H(S)$. (घ) $\mathrm{ADH}(\mathrm{S})$ free y ( $\mathrm{\square}) \mathrm{ADH}(\mathrm{S}) @ N I T Q-2$. Reaction conditions: $\mathrm{ADH}(\mathrm{S})$ (8.6 mg) or ADH(S)@NITQ-2 (208.6 mg), 2-octanone, 0.3 mmol (30 mM), NAD+, 0.03 mmol (molar ratio substrate/cofactor $=10$ ), in $10 \mathrm{~mL}$ of solvent (Isopropanol/phosphate buffer solution $\mathrm{pH} 7(50 / 50 \mathrm{v} / \mathrm{v}), 1 \mathrm{~h}$, at $25^{\circ} \mathrm{C}$. 


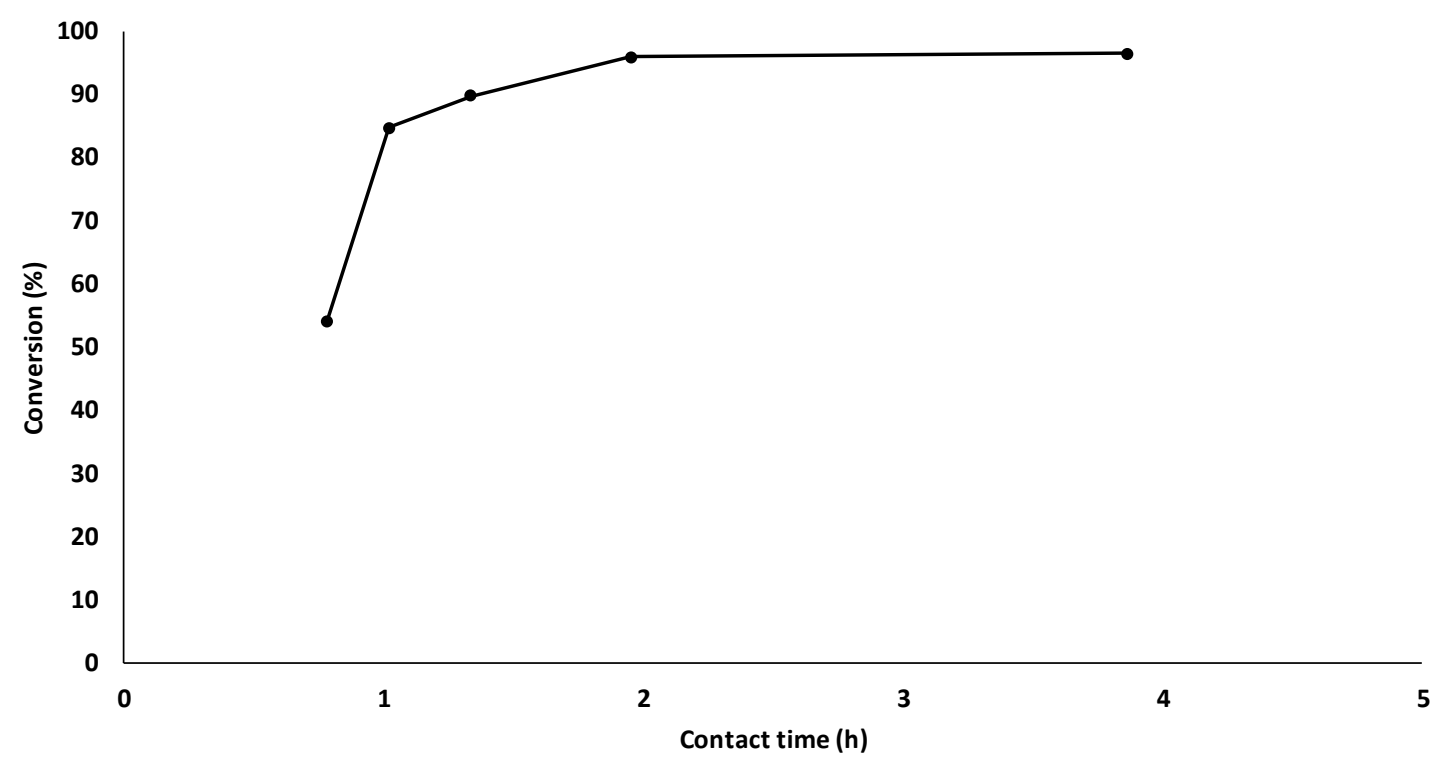

Figure S5. Evaluation of the contact time in flow reactor for the reduction of 2octanone to (S)-2-octanol. Reaction conditions: ADH(S)@NITQ-2 (208.6 mg), (molar ratio substrate/cofactor $=10$ ), $10 \mathrm{~mL}$ of solvent (Isopropanol/phosphate buffer solution $\mathrm{pH} 7(50 / 50 \mathrm{v} / \mathrm{v})$, flow $0.55 \mathrm{~mL} / \mathrm{h} 25^{\circ} \mathrm{C}$. 


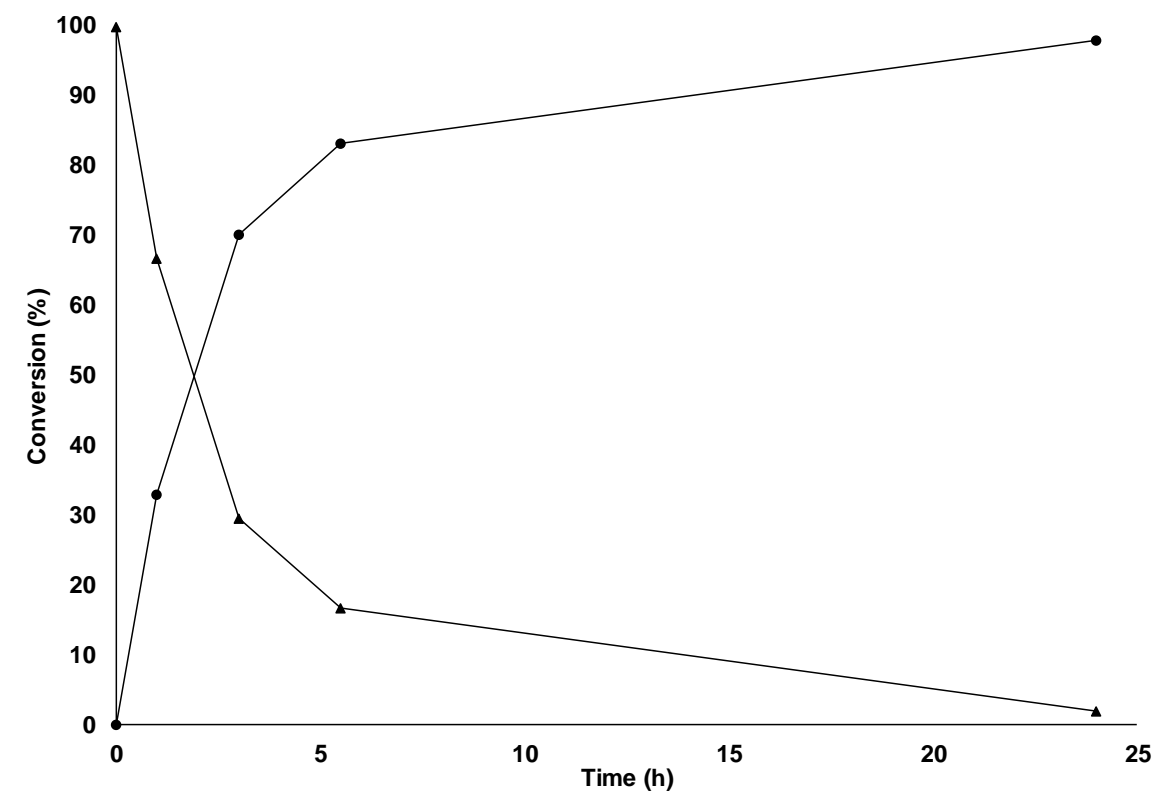

Figure S6. Oppenauer oxidation of rac-2-octanol using Zr-Beta zeolite.(४) 2octanol, $(\bullet)$ 2-octanone. Conditions: Zr-Beta $(32 \mathrm{mg})$, 2-octanol $(0.4 \mathrm{mmol})$, acetone $(1.5 \mathrm{~mL}, 20.4 \mathrm{mmol})$, at $50 \stackrel{\circ}{\circ}$. 


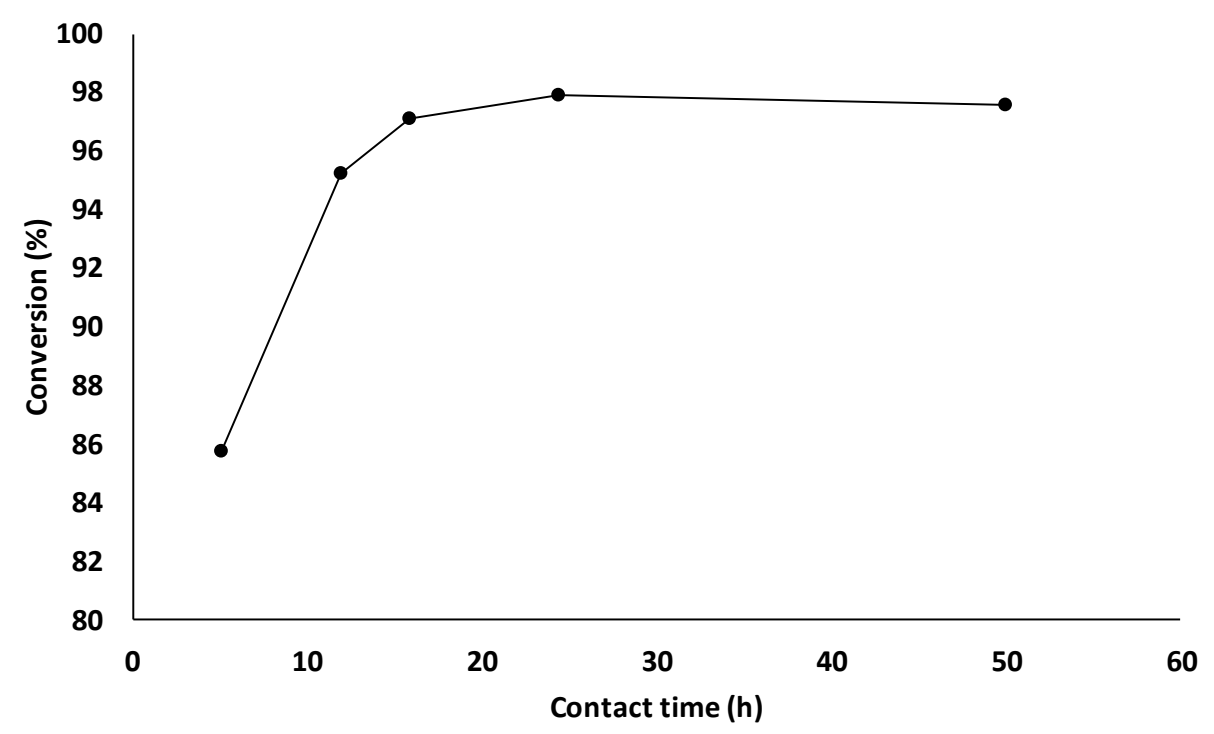

Figure S7. Evaluation of contact time in a continuos oxidation reactor. Reaction conditions: Zr-Beta (304 mg), acetone (10 mL, $136 \mathrm{mmol})$, flow $0.5 \mathrm{~mL} / \mathrm{h}$ at 50 ${ }^{\circ} \mathrm{C}$.

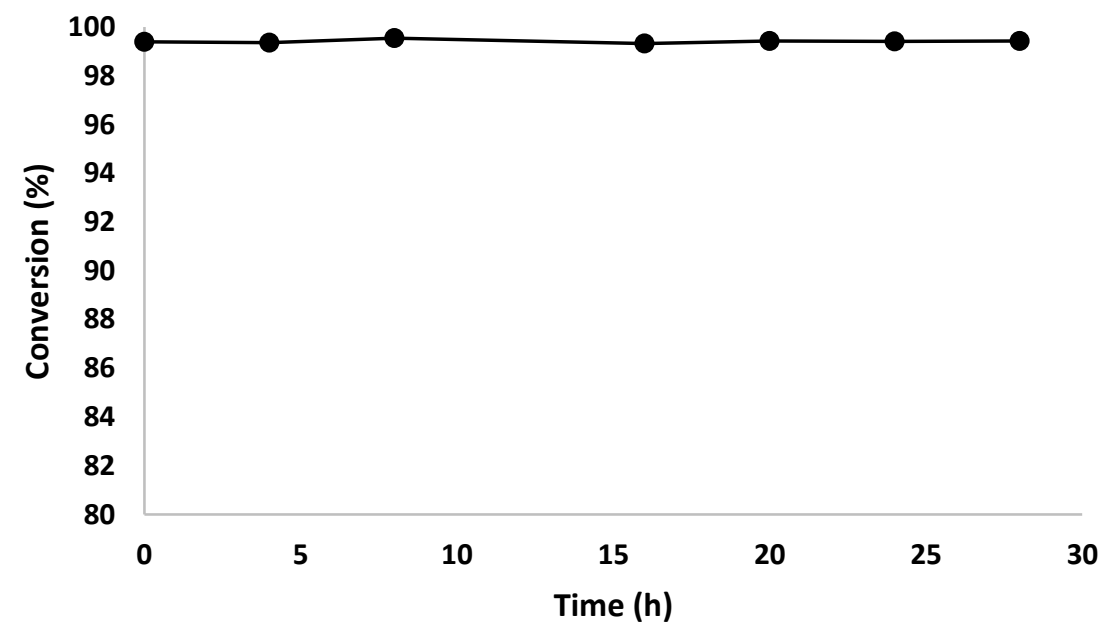

Figure S8. Evaluation of oxidation-reduction of rac-2-dodecanol in continuos reactor. Reaction conditions: First step: Zr-Beta $(301 \mathrm{mg})$, acetone $(10 \mathrm{~mL}, 136$ $\mathrm{mmol}$ ), 2-dodecanol $126 \mathrm{mmol} / \mathrm{L}$, flow $0.5 \mathrm{~mL} / \mathrm{h}$ at $50{ }^{\circ} \mathrm{C}$. Second step: ADH(S)@NITQ-2 (208.6 mg), 2-dodecanone (30 mmol/L), NAD+ (3 mmol/L), solvent (Isopropanol/phosphate buffer solution $\mathrm{pH} 7$ (50/50 v/v), flow $0.55 \mathrm{~mL} / \mathrm{h}$, $25^{\circ} \mathrm{C}$. 


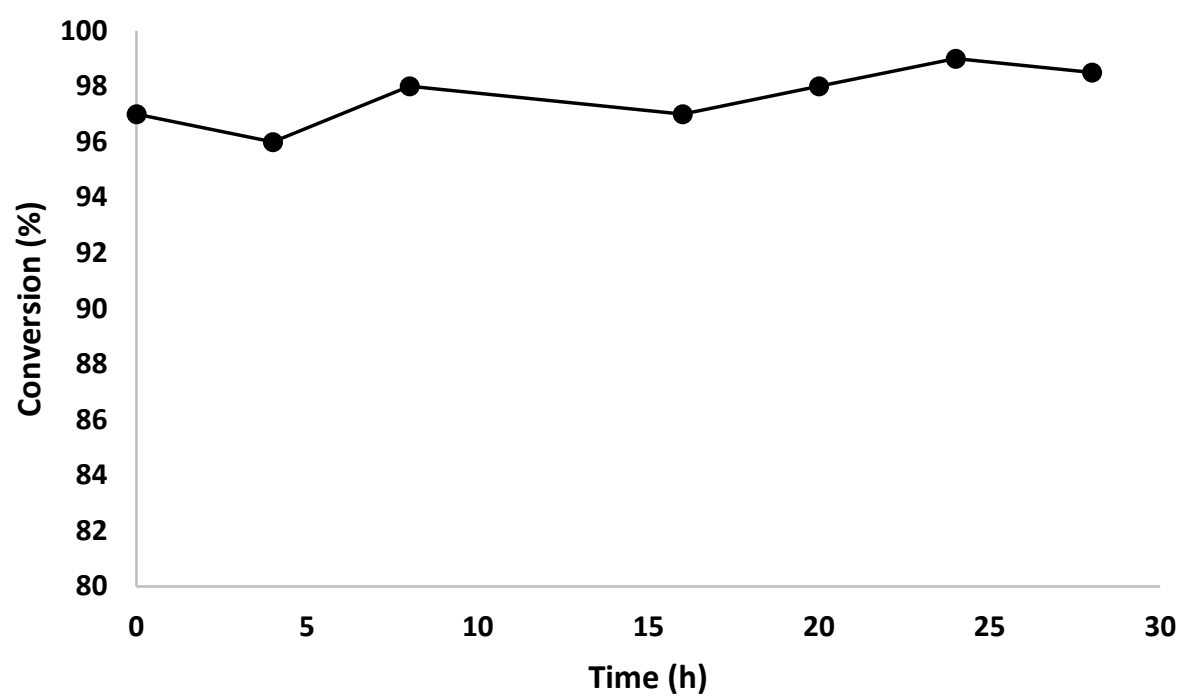

Figure S9. Evaluation of oxidation-reduction of rac-1-cyclohexylethanol in continuos reactor. Reaction conditions: First step: Zr-Beta $(610 \mathrm{mg})$, acetone $(10 \mathrm{~mL}, 136 \mathrm{mmol})$, rac-1-cyclohexylethanol $123 \mathrm{mmol} / \mathrm{L}$, flow $0.2 \mathrm{~mL} / \mathrm{h}$ at 50 ${ }^{\circ} \mathrm{C}$. Second step: ADH(S)@NITQ-2 (208.6 mg), rac-1-cyclohexylethanone (30 $\mathrm{mmol} / \mathrm{L}), \mathrm{NAD}^{+}(3 \mathrm{mmol} / \mathrm{L})$, solvent (Isopropanol/phosphate buffer solution $\mathrm{pH} 7$ $(50 / 50 \mathrm{v} / \mathrm{v})$, flow $0.55 \mathrm{~mL} / \mathrm{h}, 25^{\circ} \mathrm{C}$ 


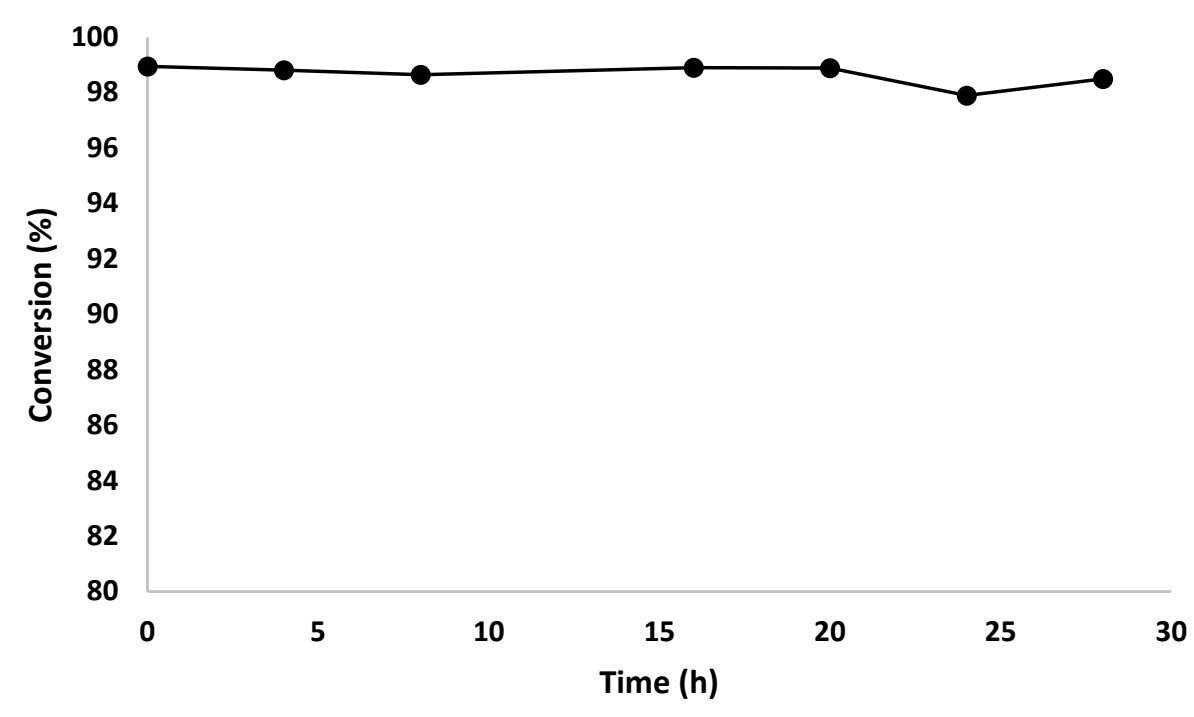

Figure S10. Evaluation of oxidation-reduction of rac-4-biphenylmethylcarbinol in continuos reactor. Reaction conditions: First step: Zr-Beta $(610 \mathrm{mg})$, acetone $(10 \mathrm{~mL}, 136 \mathrm{mmol})$, rac-4-biphenylmethylcarbinol $80 \mathrm{mmol} / \mathrm{L}$, flow $0.2 \mathrm{~mL} / \mathrm{h}$ at $50{ }^{\circ} \mathrm{C}$. Second step: ADH(S)@NITQ-2 (208.6 mg), 4-acethylbiphenyl (30 $\mathrm{mmol} / \mathrm{L}), \mathrm{NAD}^{+}(3 \mathrm{mmol} / \mathrm{L})$, solvent (Isopropanol/phosphate buffer solution $\mathrm{pH} 7$ $(50 / 50 \mathrm{v} / \mathrm{v})$, flow $0.55 \mathrm{~mL} / \mathrm{h}, 25^{\circ} \mathrm{C}$.

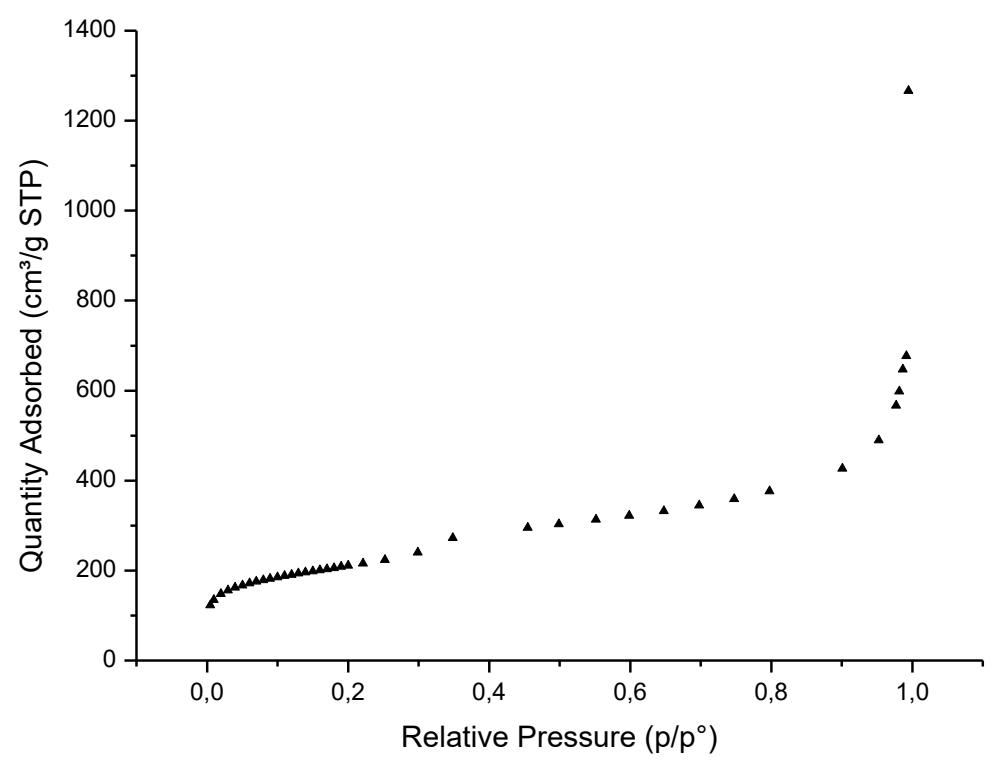

Figure S11. Nitrogen adsorption isotherm of ITQ-2 zeolite 


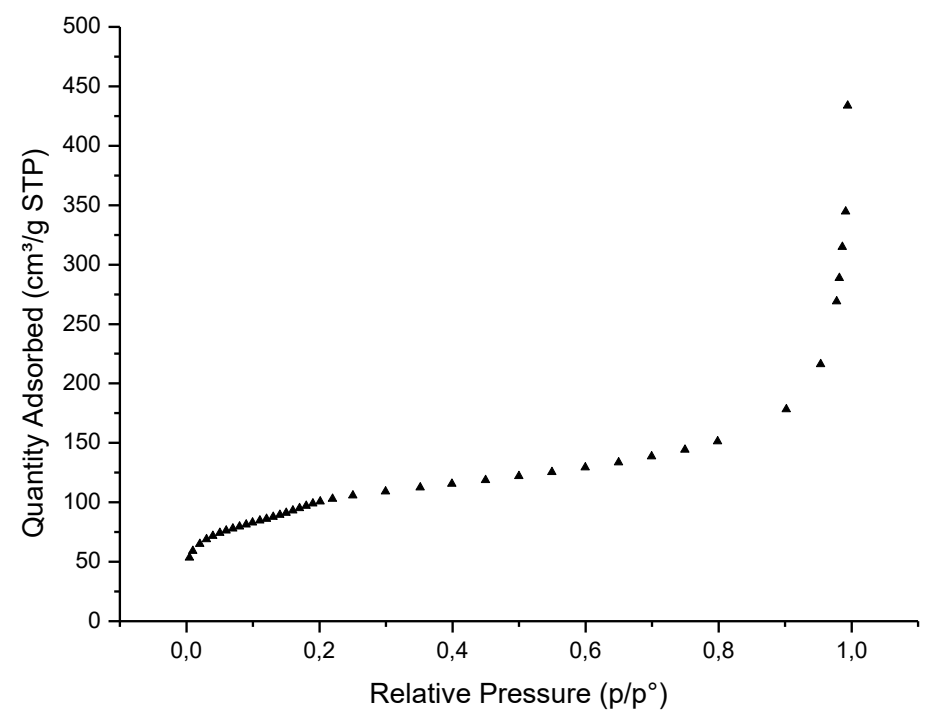

Figure S12. Nitrogen adsorption isotherm of NITQ-2 zeolite

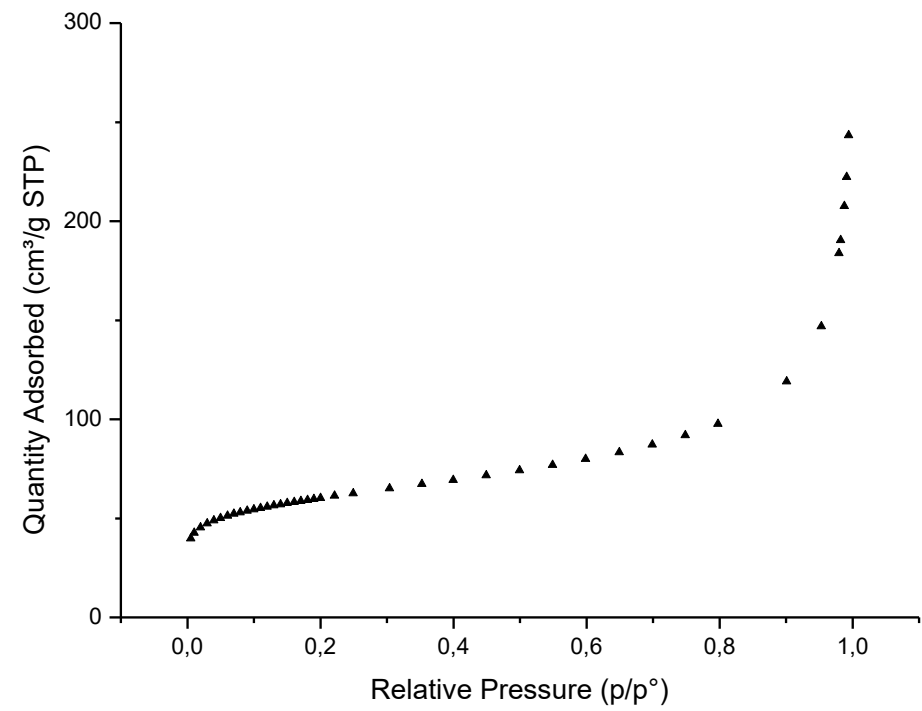

Figure S13. Nitrogen adsorption isotherm of ADH@NITQ-2 zeolite 


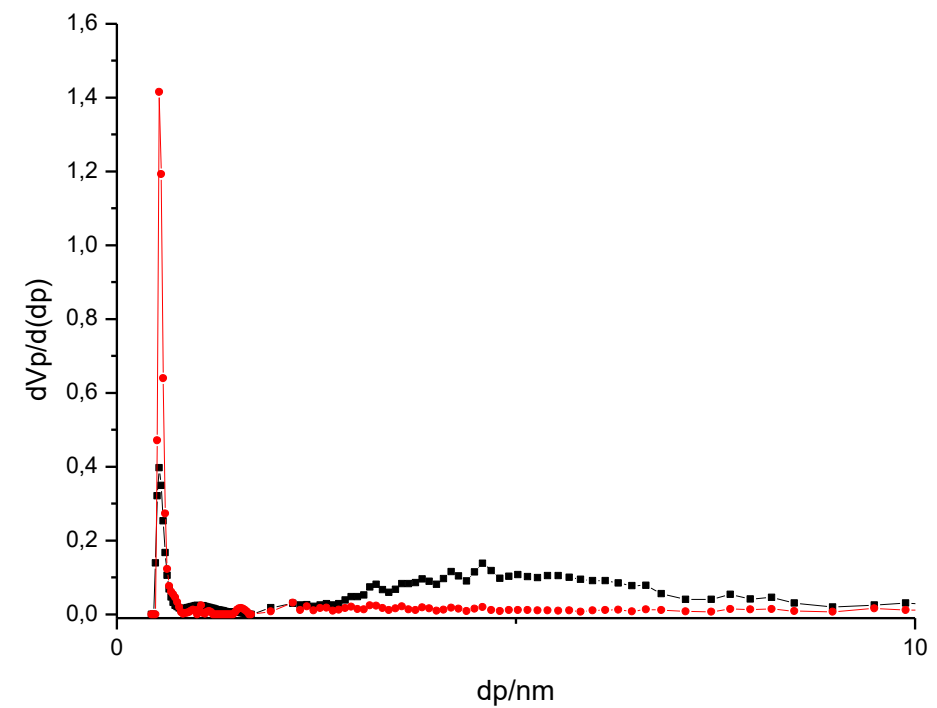

Figure S14. Pore volume distribution of ITQ2 zeolite (red) and ADH@NITQ2 (black) 